\title{
GROUNDWATER DYNAMICS BETWEEN PLANINSKO POLJE AND SPRINGS OF THE LJUBLJANICA RIVER, SLOVENIA
}

\author{
DINAMIKA PODZEMNE VODE MED PLANINSKIM POLJEM \\ IN IZVIRI LJUBLJANICE, SLOVENIJA
}

\author{
Matej BLATNIK ${ }^{1,2}$, Cyril MAYAUD ${ }^{1,2}$ \& Franci GABROVŠEK ${ }^{1,2, *}$
}

\begin{abstract}
UDC 551.444(497.4)

Matej Blatnik, Cyril Mayaud \& Franci Gabrovšek: Groundwater dynamics between Planinsko Polje and springs of the Ljubljanica River, Slovenia

Caves reaching the (epi)phreatic zone may provide the only access to groundwater in the internal parts of karst aquifers. Modern instruments enable unattended high frequency measurements of groundwater parameters in such caves. A network of distributed observation points may give new information on temporal and spatial pattern of groundwater flow. Such network, recording water level, temperature and specific electrical conductivity was established in all major ponors and active water caves of the karst aquifer between Planinsko Polje and springs of the Ljubljanica River, Slovenia. Up to three and a half years long records were analysed in view of available and relevant geological, speleological, meteorological and hydrological information, and basic hydraulic principles of the epiphreatic flow. The result of the interpretation were models of possible conduit networks of the three main flow subsystems draining Planinsko Polje. For each subsystem a hydraulic model comprising the main features of the inferred conduit network and inputs was made. The models were adjusted until their response to the typical flood situations gave a good qualitative fit to the response of the observation network. The results provide new insights into the mechanism of flood propagation through the system and its relation to the known conduit geometry. The hydraulic role of known cave passages is assessed and new flow pathways are proposed. Back-flooding within the aquifer causes an increase of head in the polje, followed by the activation of higher located ponor zones and flow pathways related to them. Hydrographs recorded in two caves located northwest from Planinsko Polje revealed pos-
\end{abstract}

\author{
Izvleček \\ UDK 551.444(497.4) \\ Matej Blatnik, Cyril Mayaud \& Franci Gabrovšek: Dinamika \\ podzemne vode med Planinskim poljem in izviri Ljubljanice, \\ Slovenija
}

Jame v epifratični coni običajno predstavljajo edini dostop do podzemne vode znotraj kraškega vodonosnika. Sodobni merilniki omogočajo kakovostne zvezne meritve različnih parametrov tudi v takšnih jamah. Merilna mreža z večlokacijami znotraj izbranega vodonosnika lahko ponudi nove podatke o časovni in prostorski dinamiki toka podzemne vode. Takšna merilna mreža, z meritvami višine, temperature in elektroprevodnosti vode, je bila vzpostavljena $\mathrm{v}$ vseh pomembnejših ponorih in vodnih jamah na območju med Planinskim poljem in izviri Ljubljanice. Do tri in pol leta dolgi nizi podatkov so bili analizirani z vidika razpoložljivih geoloških, speleoloških, meteoroloških in hidroloških podatkov ter osnovnih hidravličnih načel o epifreatičnem toku vode. Rezultat interpretacij so poenostavljeni modeli $\mathrm{z}$ domnevno razporeditvijo podzemnih kanalov v treh glavnih podsistemih, ki odvajajo Planisko polje. Za vsak podsistem je bil napravljen hidravličen model $\mathrm{z}$ dotokom in mrežo kanalov, ki najbolje ponazarja resnično stanje. Tekom raziskave so se hidravlični modeli nadgrajevali do takšne mere, da je simulacija vodnega toka zadovoljivo ponazarjala dogajanje, izmerjeno v resničnem okolju. Rezultati so prinesli nove ugotovitve o širjenju in dinamiki poplavljanja skozi sistem ter njihovo povezavo s poznano geometrijo proučevanega vodonosnika. Ocenjena je bila hidravlična vloga poznanih jamskih rovov, na podlagi njih pa interpretirane nove smeri pretakanja vode. Ugotovljeno je bilo tudi zajezitveno poplavljanje znotraj vodonosnika, ki vpliva tudi na vodostaj na polju in nadalje na aktivacijo višje ležečih požiralnikov ter njim sledečih kanalov. V dveh jamah severozahodno od Planinskega polja so višinski

${ }^{1}$ Karst Research Institute, ZRC SAZU, Titov trg 2, 6230 Postojna, Slovenia, e-mail: mblatnik@zrc-sazu.si, cyril.mayaud@zrc-sazu. si, gabrovsek@zrc-sazu.si

${ }^{2}$ UNESCO Chair on Karst Education, University of Nova Gorica, Glavni trg 8, 5271 Vipava, Slovenia

* Corresponding author 
sible high transmissivity zone of the Idrija Fault Zone and the mechanism of estavelles located at the polje's north-western border. The approach taken in this work offers new insights into the relation between the conduit network geometry and flood mechanism. It can be used elsewhere in conduit-dominated systems with multiple accesses to groundwater flow and well constrained recharge.

Key words: karst aquifer, epiphreatic zone, groundwater monitoring, hydraulic models, Planinsko Polje, Ljubljanica River hidrogrami nakazali na obstoj bolj prepustnega območja Idrijske prelomne cone ter delovanje estavel na severozahodnem obrobju polja. Postopek, ki je bil uporabljen v pričujočem delu, omogoča nova dognanja o razporeditvi podzemnih kanalov in s tem povezano dinamiko poplavljanja v kraškem vodonosniku. Predstavljeno metodo je mogoče uporabiti tudi v drugih kraških sistemih $\mathrm{z}$ dobro razvitimi kanali, $\mathrm{z}$ več dostopi do toka podzemne toka vode in dobro poznanem dotoku v sistem.

Ključne besede: kraški vodonosnik, epifreatična cona, spremljanje podzemne vode, hidravlični modeli, Planinsko polje, Ljubljanica.

\section{INTRODUCTION}

Groundwater dynamics in mature karst aquifers under active tectonic settings with mixed allogenic/autogenic recharge is hard to observe and predict. Such aquifers are challenging due to complex and largely unknown distribution of conduits, which convey most of the groundwater flow (Worthington 1999; Palmer 2007). The speleogenesis in these systems is accompanied by continuous structural changes, changes in base levels, and temporal and spatial distribution of recharge (e.g., evolution of poljes) (Palmer 2007). All these factors create complex and apparently poorly organised multiple levelled system of conduits with highly variable geometry, where the conduit cross-section may change abruptly or may be terminated by breakdowns. Combined with variable recharge conditions, this results in rapid and strong variations of groundwater level in the epiphreatic zone during rain events (Gabrovšek et al. 2014).

Most studies focusing on groundwater flow in karst aquifers are limited to recharge-discharge relationship using spring hydrograph analyses and tracing techniques (Berthelin \& Hartmann 2020).

However, recent development of instrumental technology allows spatially distributed continuous records of basic groundwater parameters, such as pressure (depth), temperature, and specific electrical conductivity (SEC) in environments where this was not possible before (Goldscheider \& Drew 2007). In the absence of boreholes, the spatial density of measurement locations relies solely on the number of caves with access to groundwater flow, which depends on the number of known entrances and on the history of caving exploration in the aquifer. Therefore, observation networks combined with robust interpretation techniques may give important insights into the nature of the aquifer.

In many areas, the thickness of the vadose zone makes the approach to groundwater level difficult. Even though modern instruments are autonomous, the problem of obtaining long-term and continuous datasets re- mains. Several studies report on observation and interpretation of groundwater level from alpine cave systems. In Grotte de Chamois in France (Audra \& Nobécourt 2012) and Bärenschacht in Switzerland (Häuselmann et al. 2003) the data were used to assess the cave geometry. Similarly, Jeannin (2001) combined speleological observations with water level measurements and hydraulic calculations to relate groundwater dynamics to the geometry of a Swiss cave. Finally, long-term monitoring of the epiphreatic flow has been made in Kras/Carso system since more than 15 years. There, datasets from 6 epiphreatic caves were used to build a conceptual and numerical hydraulic model, which successfully reproduced the measured time series under different hydrological situations (Cucchi \& Zini 2002; Gabrovšek \& Peric 2006; Gabrovšek et al. 2018).

In this work, we present the last research that was implemented in the northern part of the Ljubljanica River recharge area, more precisely in the aquifer located in the area between Planinsko Polje and springs of the Ljubljanica River near Vrhnika (Figs. 1 \& 2).

An observation network of autonomous dataloggers recording water level, temperature and specific electric conductivity was installed in all major ponors and epiphreatic caves located in the area. Up to three and a half years long records with numerous high water events were analysed and combined with complementary available meteorological, hydrological, speleological and geological data. The objective was to identify the main flow pathways in the aquifer as well as the mechanisms of flood propagation through the system. Further objectives included an analysis of the interaction between the polje and its adjacent aquifer, and the identification on how large tectonic structures may affect groundwater flow patterns. Besides regional implications, the goal was to further develop a method, combining groundwater observations within the epiphreatic system and data interpretation based on simple 
hydraulic models, which could be applied to other karst systems.

The paper is organised as follows: basic hydrogeological characteristics of the observed region precede a description of the methods employed. The area under investigation is divided in three subsystems and the groundwater dynamics in each of these subsystems is described in separate sections. Finally, an overview of the stages composing typical flood events is given. The conclusions outline the basic findings and point out to further research.

\section{THE STUDY AREA}

The Ljubljanica River recharge area (Fig. 1) is located in central Slovenia and structurally belongs to the External Dinarides (Placer et al. 2010). It is a tectonically diverse area with numerous thrusts, nappes and faults, resulting in depressions and plateaus with a predominantly NWSE orientation (Placer 1981; Placer et al. 2010). Most of the area is underlain by a thick sequence of highly karstified Cretaceous and Jurassic limestones and less permeable Jurassic and Triassic dolomites (Pleničar 1970; Gospodarič \& Habič 1976; Krivic et al. 1976).

Despite its proximity to the Adriatic Sea, the water is drained northwards towards the Ljubljana Basin and belongs to the Black Sea basin. The area is dissected by a regional NW-SE trending fault zone called the Idrija Fault Zone (IFZ). The IFZ acts as a flow barrier for the water coming from the mountainous Notranjska Region and the Pivka Basin (Fig. 2). This led to the formation of a set of successive poljes distributed along the IFZ, where the groundwater is forced to surface (Gams 1965; Gospodarič \& Habič 1976; Šušteršič 1996; Šušteršič 2002; Vrabec 1994). The last in the line is Planinsko Polje, where most of the water emerges, flows over the polje and sinks back into the karst aquifer.

This work focuses on the aquifer situated between Planinsko Polje (435-450 $\mathrm{m}$ a.s.l.) and springs of the Ljubljanica River (295-300 m a.s.l.), that are located at the border of Ljubljana Basin (Fig. 2). The aquifer is fragmented into smaller sub-units by numerous faults with prevailing Dinaric (NW-SE) and Transdinaric orientation (Šušteršič 2002). Large part of the area belongs to the Ravnik Plateau (Fig. 2), a levelled region located between 500 and $800 \mathrm{~m}$ a.s.l with high density of dolines and caves (Šušteršič 2002). The thickness of the vadose zone varies between $50 \mathrm{~m}$ in the proximity of Planinsko Polje and the Ljubljanica Springs, and up to $500 \mathrm{~m}$ in the mountainous hinterland of the springs. There are more than 800 caves known in the area of about $150 \mathrm{~km}^{2}$ (average depth $20 \mathrm{~m}$, average length $50 \mathrm{~m}$; Cave Register 2019), but only 10-15 caves reach the epiphreatic zone. Most of them are located close to Planinsko Polje, the most distant lies about $4 \mathrm{~km}$ north from the polje (Fig. 2).
The structure of both epiphreatic and vadose zones is complex. The caves occupy multiple levels although these are not distinctively organised (Gospodarič 1981). They are characterised by a highly irregular geometry and often terminated by breakdowns. This is a common feature present in the Dinaric Karst, where active tectonics keep the systems out of speleogenetic equilibrium; i.e., the state, where conduits are large enough to accommodate large flood events (Gabrovšek et al. 2014). Due to irregular geometry and a high recharge variation the epiphreatic zone is very dynamic: the water may rise up to $60 \mathrm{~m}$ during flood events, activating many overflow passages (Gabrovšek \& Turk 2010). Presently, we do not know much about the structure of the phreatic zone. In the immediate vicinity of the main springs of the Ljubljanica River, there are two known warm springs (Brenčič 2008), which possibly indicate presence of deep regional flow.

Recharge of the system is manifold. An autogenic component gives rise to initial response of the system. Part of the water coming from the Hrušica Plateau and Cerkniško Polje flows directly to the springs of the Ljubljanica River and therefore bypasses Planinsko Polje (Gospodarič \& Habič 1976). The main contribution comes from the Unica River, which flows over Planinsko Polje and sinks along its ponor zones. Planinsko Polje is $10 \mathrm{~km}^{2}$ large and captures water from the cascading set of Notranjska poljes on the south-east and from the Pivka Basin, Javorniki Mountains and part of Snežnik Mountains on the south (Fig. 1). Most of these waters merge in Planinska Jama (Planina Cave), where they are distributed in a unique way towards the Malni and the Unica springs (Gabrovšek et al. 2010; Kaufmann et al. 2019). Both springs are tributaries of the Unica River (Fig. 2) with a mean annual discharge of $21 \mathrm{~m}^{3} / \mathrm{s}\left(\mathrm{Q}_{\min }\right.$ $=1.1 \mathrm{~m}^{3} / \mathrm{s}, \mathrm{Q}_{\max }=\sim 100 \mathrm{~m}^{3} / \mathrm{s}$; Frantar 2008). The Unica River flows for $17 \mathrm{~km}$ across Planinsko Polje. About $7 \mathrm{~km}$ downstream from the springs, part of the water start to sink through several ponors located on the polje's eastern border. This ponor zone consists of numerous swallow holes and highly fractured leakage zones that are 
distributed along a $2 \mathrm{~km}$ long line. Blatnik et al. (2017) used an ADCP device to measure the outflow capacity of the main ponors and estimated a total outflow of 18 $\mathrm{m}^{3} / \mathrm{s}$ at the time of measurements. This value is close to the estimated maximal outflow along the eastern ponor zone (Šušteršič 2002). During higher flow conditions, the excess of water flows for $10 \mathrm{~km}$ towards the polje's northern border. There, the channel network distributes water into several ponor groups: the main two are called Pod Stenami and Škofov Lom (Fig. 2). The total outflow sinking through the northern ponors is estimated to be between 40 and $60 \mathrm{~m}^{3} / \mathrm{s}$ (Šušteršič 2002). In addition, several estavelles and overflow springs are located below the village of Grčarevec at the north-western border of the polje. These may discharge/drain up to several cubic meters per second (Savnik 1960). The total outflow from Planinsko Polje is estimated to be at least of $60 \mathrm{~m}^{3} / \mathrm{s}$ (Šušteršič 2002). When the inflow is higher than the outflow, Planinsko Polje is flooded (Kovačič \& Ravbar 2010; Mayaud et al. 2019). This occurred on average for 38 days per year between 1954 and 2014 (Ravbar et al. 2018).

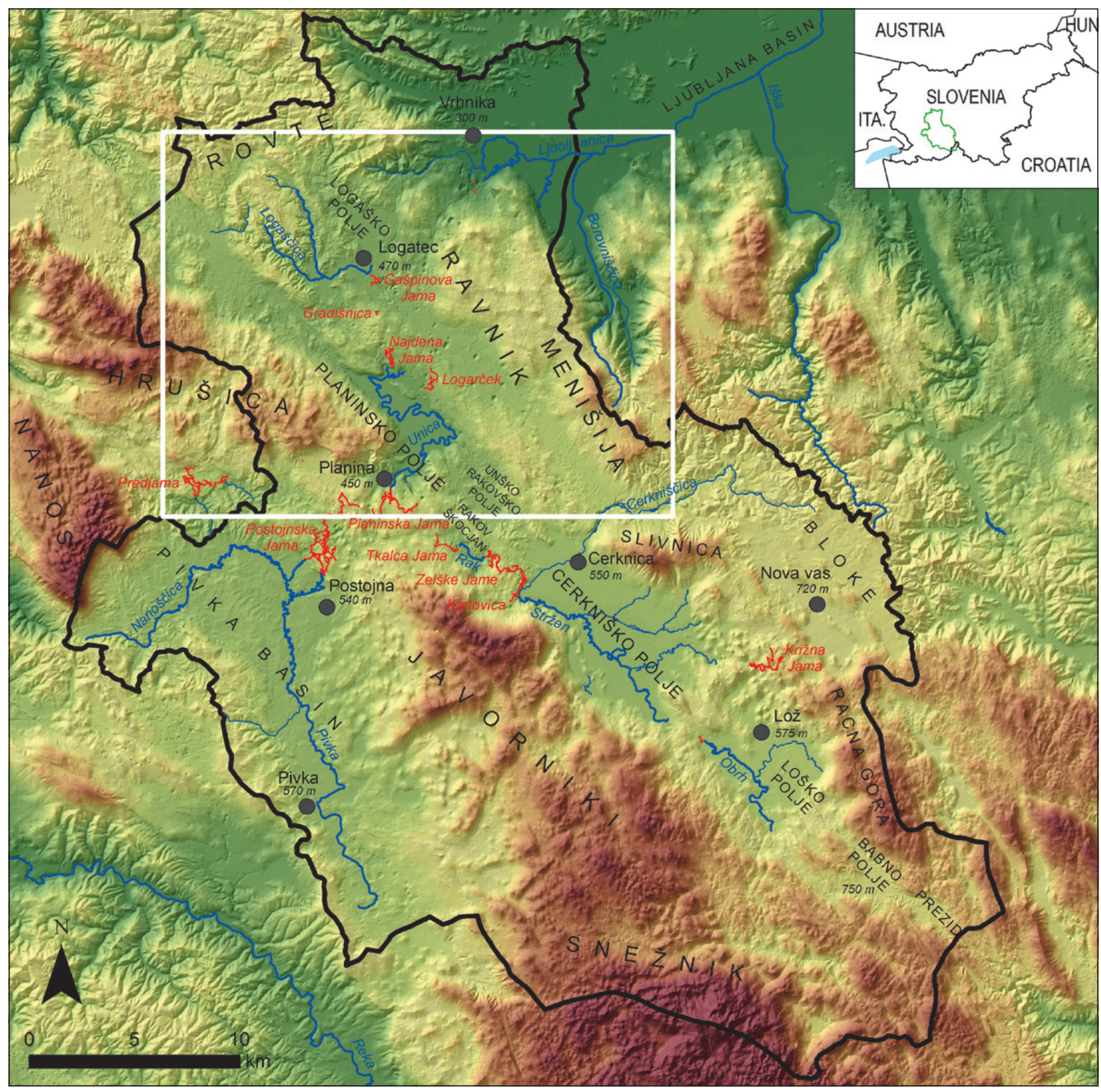

Fig. 1: The Ljubljanica River recharge area (black line) with major surface streams and cave systems (DEM data from ARSO 2019c; Cave data from Cave Register 2019). The study area is marked with a white rectangle. Inset: Regional position of the Ljubljanica River recharge area (green line). 
Many studies have been dedicated to understand flooding mechanisms of Planinsko Polje. First works focused on enhancing the polje outflow capacities and recommended a widening of the main ponors for mitigation of floods (Putick 1889; Shaw \& Čuk 2015). Later studies were focused on understanding the interaction of the polje with its surrounding aquifers (Gams 1980; Kovačič \& Ravbar 2010; Frantar \& Ulaga 2015; Ravbar et al. 2018; Mayaud et al. 2019). Comprehensive tracing experiments carried out in the 1970s revealed the main groundwater flow directions and determined the flow velocities under different hydrological conditions. These studies also revealed a complex intertwined flow within the aquifer (Gospodarič \& Habič 1976). This work pres- ents an extension of the research done previously by Turk and Gabrovšek (Gabrovšek \& Turk 2010; Turk 2010), which was based on an observation network established in four caves. These authors proved several hydraulic connections within the observed parts of the system, and showed that the limited capacity of the eastern ponor zone leads to the diversion of Unica River towards the northern ponors. However, their conclusions were limited by the small number of observation points and by the fact that ponors were not integrated in the measurement network. The present work includes the monitoring of three important ponor groups and extends the number of observation points to most known water caves existing in the area.

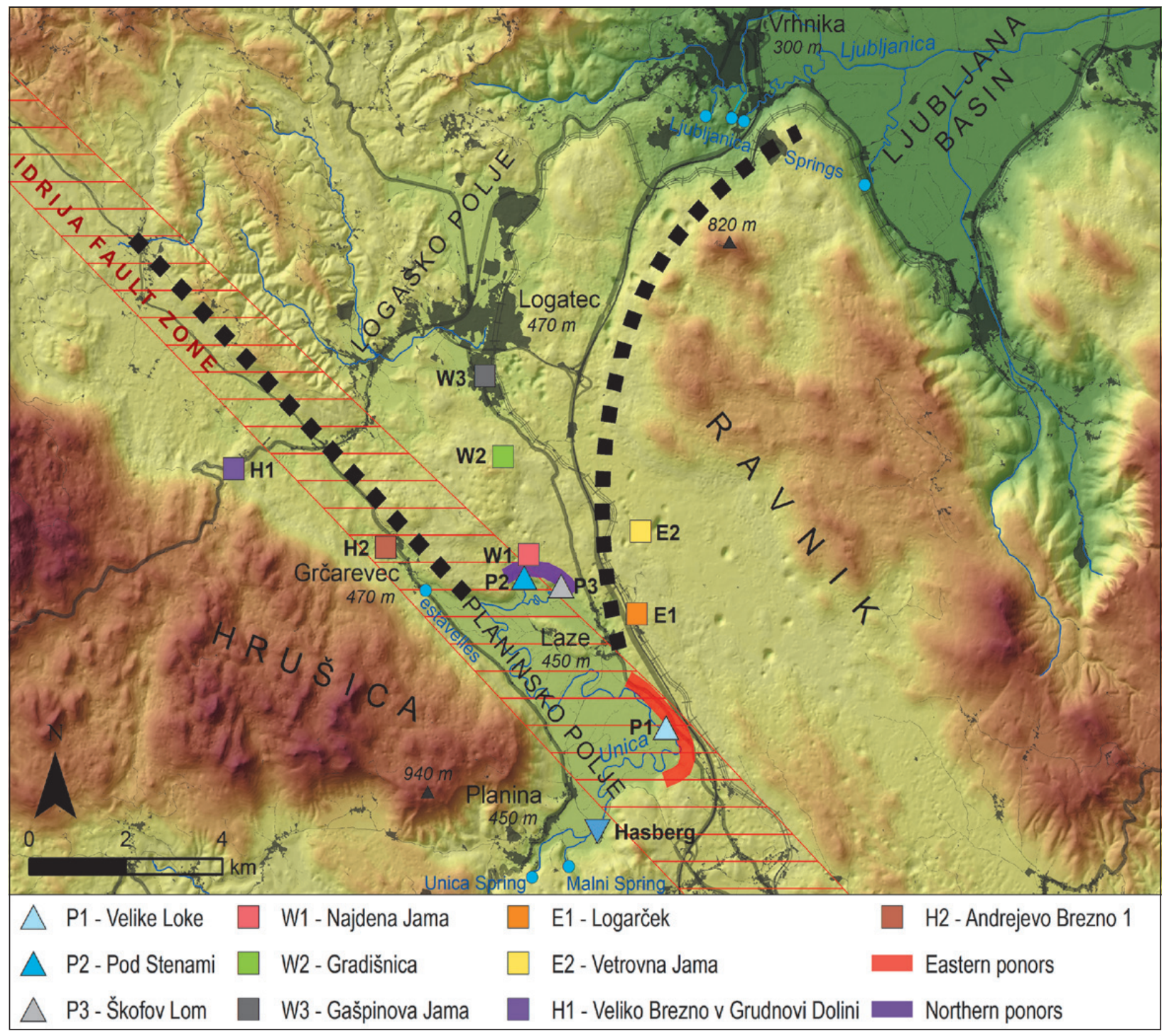

Fig. 2: Detailed map of the study area showing all observation points: monitored ponors are marked by triangles and water active caves by squares (DEM data from ARSO 2019c; Cave locations from Cave Register 2019). The delineation between three main subsystems, marked by thick dashed lines, is based on the previous studies (Gospodarič \& Habič 1976; Gabrovšek \& Turk 2010; Turk 2010). 
The observed aquifer is large and complex. Evidences from past research (Gospodarič \& Habič 1976; Šušteršič 2002; Gabrovšek \& Turk 2010; Turk 2010) show that the area under investigation can be subdivided into the following hydrogeological subsystems (Fig. 2):

- the subsystem which is mainly recharged through the eastern ponor zone: ponor Velike Loke (P1), cave Logarček (E1) and cave Vetrovna Jama pri Laški Kukavi (E2).

- the subsystem primarily recharged through the north- ern ponor zone: ponors Pod Stenami (P2) and Škofov Lom (P3), caves Najdena Jama (W1), Gradišnica (W2), and Gašpinova Jama (W3).

- the subsystem located on the southwestern side of the Idrija Fault Zone in the northwest of Planinsko Polje, which is mainly recharged from the Hrušica Plateau and Hotenjka region. This subsystem includes the caves Veliko Brezno v Grudnovi Dolini (H1) and Andrejevo Brezno 1 (H2).

\section{METHODS}

\section{ESTABLISHMENT OF AN AUTONOMOUS MEASUREMENT NETWORK}

An autonomous measurement network was established at 3 ponors and 7 caves at different locations in the studied aquifer (Fig. 2). The instruments recorded water level, temperature and specific electrical conductivity (SEC).

Schlumberger (Diver Mini) and Onset Hobo (U20) programmable autonomous instruments were used to measure water level and temperature (Fig. 3). Onset Hobo U24 was used for measurement of EC (Fig. 3). The pressure range of instruments was selected to be higher than the pressures exerted by the highest estimated water rise in caves. The accuracy of pressure measurements is \pm 0.25 $\%$ of the measurement range, the accuracy of temperature sensors is \pm 0.1 to $\pm 0.2^{\circ} \mathrm{C}$ and the accuracy of conductivity is $5 \mu \mathrm{S} / \mathrm{cm}$ (ONSET Comp 2018a; ONSET Comp 2018b; Schlumberger Water Services 2018). The measurement interval was set to $1 \mathrm{~h}$. The measurement period analysed in this work was between January 2015 and May 2018 at most locations. The observation, however, still continues at some points. To extract the changes in water level, pressure data were compensated using barometric records from the Ljubljana meteorological station.

The ponors and caves selected for the observation network are shown in Figs. 2 and 4 and listed in Tab. 1.

- P1 is a ponor located within the eastern outflow zone and connected to the Unica River by a $50 \mathrm{~m}$ long channel. There, the flow enters the aquifer through many solutionally enlarged fractures and small conduits.

- E1 is a $5 \mathrm{~km}$ long, mostly horizontal cave. The entrance is located about $1 \mathrm{~km}$ northeast from the eastern ponors. The instrument was placed into the lowest known sump called Bukovčev Rov, where water can drop for about 22 $\mathrm{m}$ below the logger during extreme draught.

- E2 is about $700 \mathrm{~m}$ long and $115 \mathrm{~m}$ deep cave located $3 \mathrm{~km}$ northeast from Planinsko Polje. The instrument was installed into the inflow sump.
- P2 belongs to the ponor zone Pod Stenami, located at the northern border of Planinsko Polje. To prevent clogging, the ponor was artificially widened, walls reinforced and entrance covered by a metal grating in early 1900 s.

- P3 is a $100 \mathrm{~m}$ long ponor cave in the ponor zone Škofov Lom, about $600 \mathrm{~m}$ SE from P2.

- W1 is an over $5 \mathrm{~km}$ long cave system with many accesses to the groundwater. The cave is about $500 \mathrm{~m}$ north of the polje's northern border. The instrument was positioned into a sump terminating the passage called Desni Rov v Lijaku.

- W2 is located about $2 \mathrm{~km}$ north of W1. The entrance is an $80 \mathrm{~m}$ deep shaft that continues down with a $20 \mathrm{~m} \mathrm{x}$ $20 \mathrm{~m}$ steeply inclined channel. The channel opens into a large chamber with an access to groundwater. The instrument was installed at the edge of a sump that was explored to a depth of $50 \mathrm{~m}$.

- W3 is located about $1.5 \mathrm{~km}$ north of W2 below the town of Logatec. The cave is a $3 \mathrm{~km}$ long sequence of large epiphreatic channels connected/bypassed by smaller passages.

- H1 is a vertical cave located at the foot of Hrušica Plateau. The shaft reaches the water at a depth of $60 \mathrm{~m}$ and continues for at least $30 \mathrm{~m}$ below the water surface. During extreme floods, the water level can rise up to the entrance and the cave becomes a spring (Mihevc 2014).

- H2 is located below the Hrušica Plateau close to the village Grčarevec. It is an about $50 \mathrm{~m}$ deep vertical cave whose lowest part is reached by water during the highest flood events.

The instruments were fixed to cave walls at low water position of the streams or lakes (Fig. 3). The micro-locations of the observation points (Fig. 4) were selected based on the following criteria:

- Continuous record: to avoid extended periods with instruments out of the water, the instruments were installed at low water conditions. 
Tab. 1: List of monitored ponors and caves with basic characteristics.

\begin{tabular}{|l|c|c|c|c|c|}
\hline Observation point & Length $(\mathbf{m})$ & Depth $(\mathbf{m})$ & $\begin{array}{c}\text { Elevation at } \\
\text { the entrance } \\
(\mathbf{m} \text { a.s.I.) }\end{array}$ & Coordinate X & Coordinate Y \\
\hline P1: ponor Velike Loke & $/$ & $/$ & 442 & 444565 & 78270 \\
\hline E1: Logarček & 4888 & 120 & 497 & 443553 & 80340 \\
\hline E2: Vetrovna Jama pri Laški Kukavi & 700 & 114 & 520 & 444100 & 82143 \\
\hline P2: ponor Požiralnik 1 Pod Stenami & 37 & 19 & 441 & 441641 & 81175 \\
\hline P3: ponor Požiralnik 1 v Škofovem Lomu & 158 & 28 & 441 & 442338 & 81013 \\
\hline W1: Najdena Jama & 5216 & 121 & 518 & 441800 & 81619 \\
\hline W2: Gradišnica & 1170 & 250 & 577 & 441087 & 83690 \\
\hline W3: Gašpinova Jama & 3375 & 103 & 482 & 441080 & 85450 \\
\hline H1: Veliko Brezno v Grudnovi Dolini & 110 & 90 & 495 & 435605 & 83315 \\
\hline H2: Andrejevo Brezno 1 & 81 & 52 & 487 & 438725 & 81815 \\
\hline
\end{tabular}

- Representativeness: the observed points must be hydraulically connected to the regional groundwater flow, i.e., vadose streams or perched lakes were avoided.

- Accessibility: the closest possible location with characteristics given above was chosen in order to minimise effort and time required for a regular data acquisition (about twice a year).

Nevertheless, several instruments were installed at depths up to $200 \mathrm{~m}$ below the surface and up to $1.5 \mathrm{~km}$ away from the cave entrance. In some caves there was simply no other option than to position the instrument in stagnant lake/sumps. This allowed a good sensitivity to measure changes in water level, but a poor temperature and SEC record as the water is only oscillating dur- ing smaller events and actual inflow of the event water passes the instrument only if there is flow into an overflow channel.

All autonomous measurements were supported with field measurements of water temperature and SEC. These measurements were carried out under particular hydrological situations and were used for calibration to control the validity of the autonomous measurements.

Finally, the discharge of the Unica River was recorded at the Hasberg gauging station. Rainfall data were taken from 8 weather stations located within the Ljubljanica River recharge area. Both datasets were obtained from the Slovenian Environmental Agency (ARSO 2019a; ARSO 2019b).

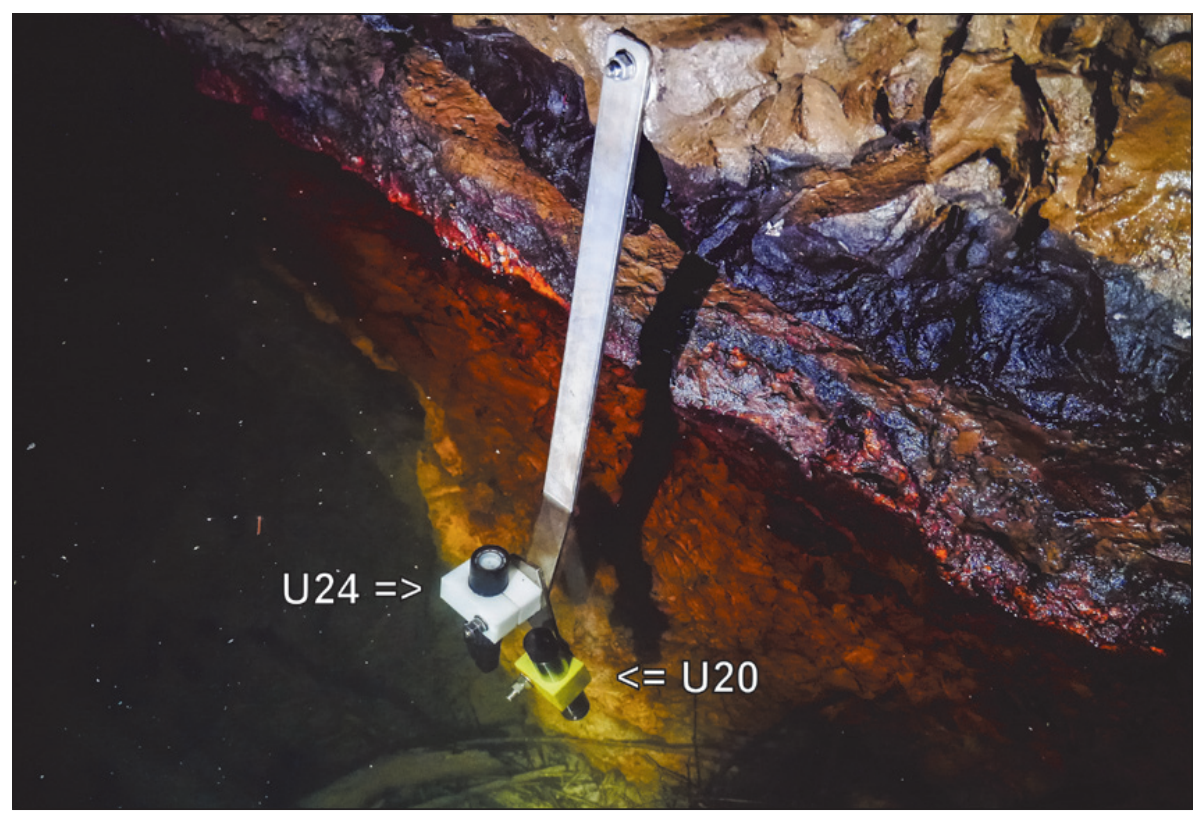

Fig. 3: Typical measurement station with Onset Hobo instruments (left: U24 - temperature and SEC measurements; right: U20 - pressure and temperature measurements). The instruments are installed within a plastic holder attached to the stainless rod, which is fixed to the wall just above the low stand water level (Photo: $M$. Blatnik) 


\section{SYSTEM RELATED TO THE EASTERN PONORS}

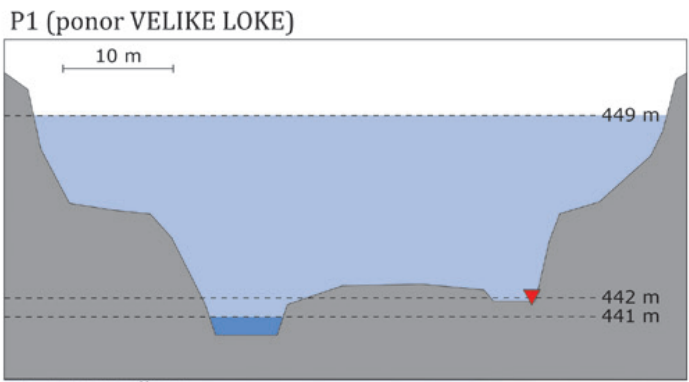

\section{E1 (LOGARČEK)}

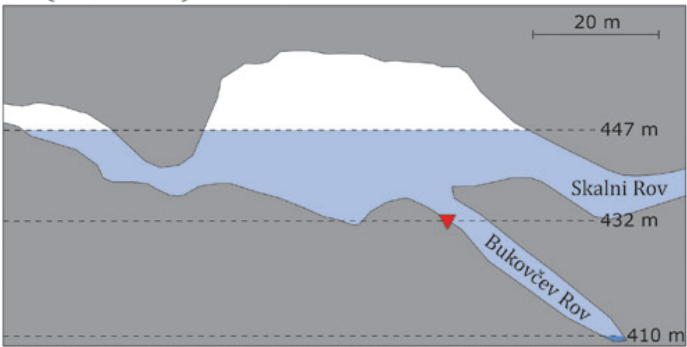

E2 (VETROVNA JAMA PRI LAŠKI KUKAVI)

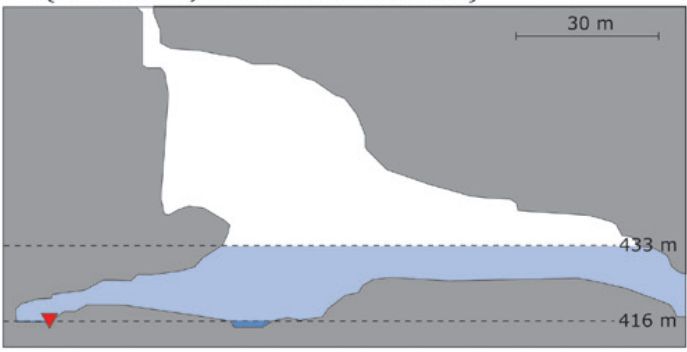

SYSTEM RELATED TO THE HRUŠICA PLATEAU

H2 (ANDREJEVO BREZNO 1) H1 (VELIKO BREZNO V GRUDNOVI DOLINI)
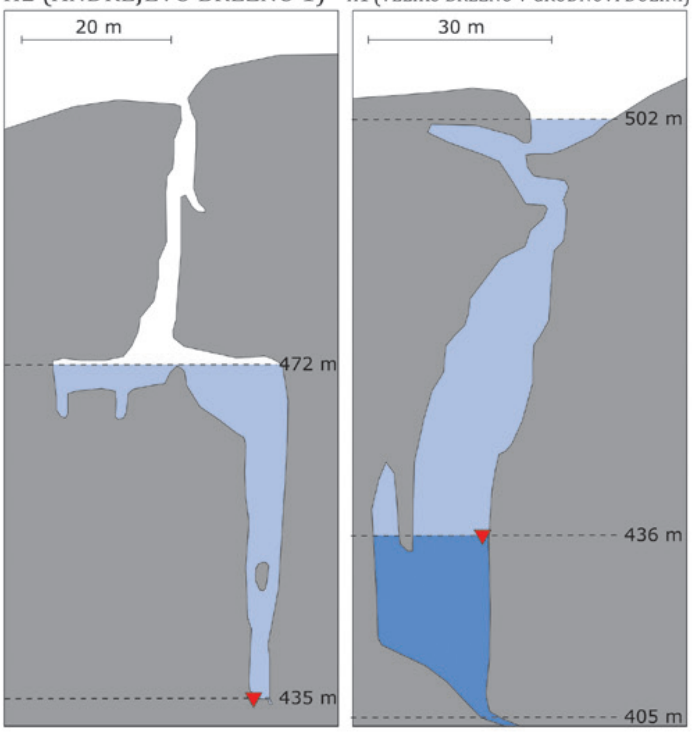

\section{SYSTEM RELATED TO THE NORTHERN PONORS}

P2 (ponor POD STENAMI)

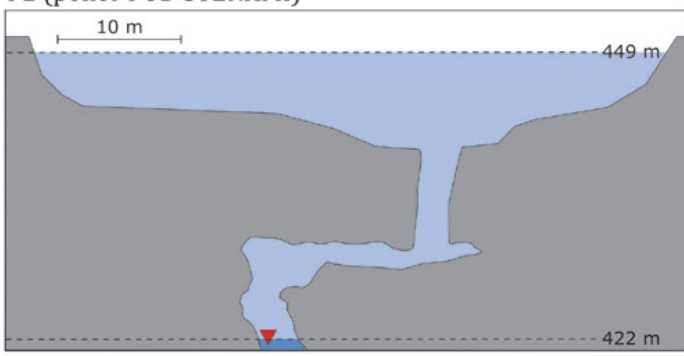

P3 (ponor ŠKOFOV LOM)
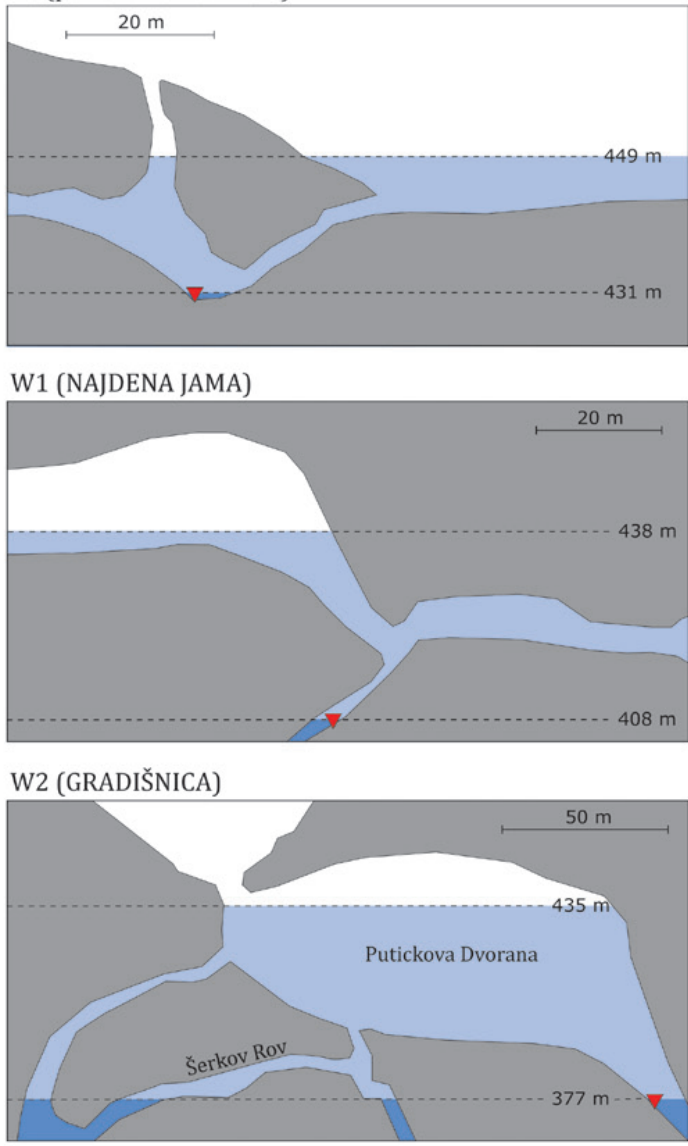

W3 (GAŠPINOVA JAMA)

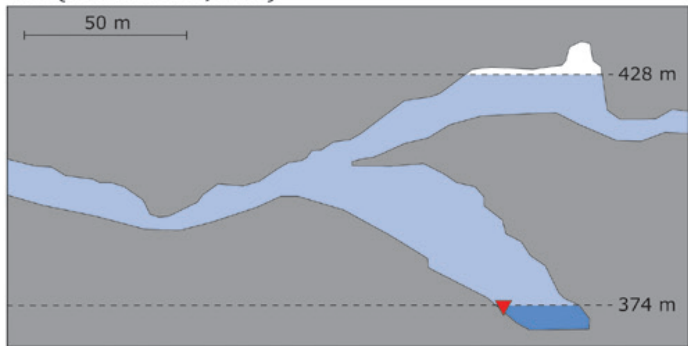

Fig. 4: Schematic view of all observation points. Red triangles indicate the position of the instruments. Dark and pale blue areas mark respectively the lowest and highest water level measured or estimated during the observation period. Cave cross-sections were adapted from Cave Register (2019). 


\section{DATA INTERPRETATION AND NUMERICAL MODELLING}

Analysis of water level hydrographs provided the major source of information used in this work. Water temperature and SEC hydrographs were only used to additionally support conclusions on possible flow connections and overflow phenomena.

\section{Interpretation of hydrographs}

Different plots of relative and absolute water level as a function of time were used to identify characteristic features on hydrographs occurring during typical events. In addition, correlation plots between water levels at different positions were used to study the hydraulic relations between the observation stations. All hydrographs and correlation plots were carefully analysed in view of known cave geometry and basic hydraulic principles of epiphreatic flow.

The analyses are based on the systematic identification of inflections in the level hydrographs, as these features are important indicators of the conduit system geometry (Gabrovšek et al. 2018, Gabrovšek et al. 2019). At any position of the water level, the slope of the hydrograph is proportional to the difference between the inflow and outflow, and inversely proportional to the local storage. Therefore, a change in the slope indicates changes of these variables. In an open channel, the level increases sub-lineary with increasing flow rate, as the flow rate increase is compensated with the increase of the flow crosssection. When the channel becomes pressurised, the flow cross-section is fixed and the head to drive flow through a conduit increases parabolically with increasing flow rate. Fig. 5a shows an increase of water level with increasing flow rate in a chamber that is drained by an initially open channel. When the flow regime in the channel changes from open surface to pressurised, the level-discharge curve changes from sublinear to superlinear. If the water level reaches a higher positioned conduit (Fig. 5b), this initially drains water efficiently as an open surface channel, so that the level-discharge curve flattens (Fig. 5b). When/if the overflow conduit becomes pressurised, another inflection to parabolic relation follows (Gabrovšek et al. 2018, Gabrovšek et al. 2019). To extract such "geometrical" inflections from those related to the recharge, we looked for particular levels where such inflections occur during all events, when the water rose to or above such level. Based on the reasoning given above, we introduce plots, where the slope of the level hydrographs (is plotted against the water level. When cumulative cloud of data points including series of events is plotted, clear minima appear at the levels of known overflows or may indicate yet unknown overflow positions (Fig. 16).

Analysis of water temperature hydrographs has several implications. For example, the time lags between diurnal cycles imposed by the concentrated inflow of the Unica River allowed an estimation of transit times between consecutive monitored points along identified flow paths. In addition, diurnal temperature signal was also used to identify overflow phenomenon in the aquifer. Finally, changes in temperature signal can mark the arrival of different water components (Turk 2010; Covington et al. 2011; Gabrovšek et al. 2018).

\section{Numerical modelling}

Hydrographs were initially analysed in view of hydraulic principles and local geometry. Hydrogeological conceptual models were built and their validity tested with analogue hydraulic numerical models. The response of the models to typical flood events was compared to the response observed in the field. The models were adapted by adding conduits or changing their position and dimension until a good qualitative fit was achieved.

Numerical models were constructed using the Storm Water Management Model (SWMM) developed
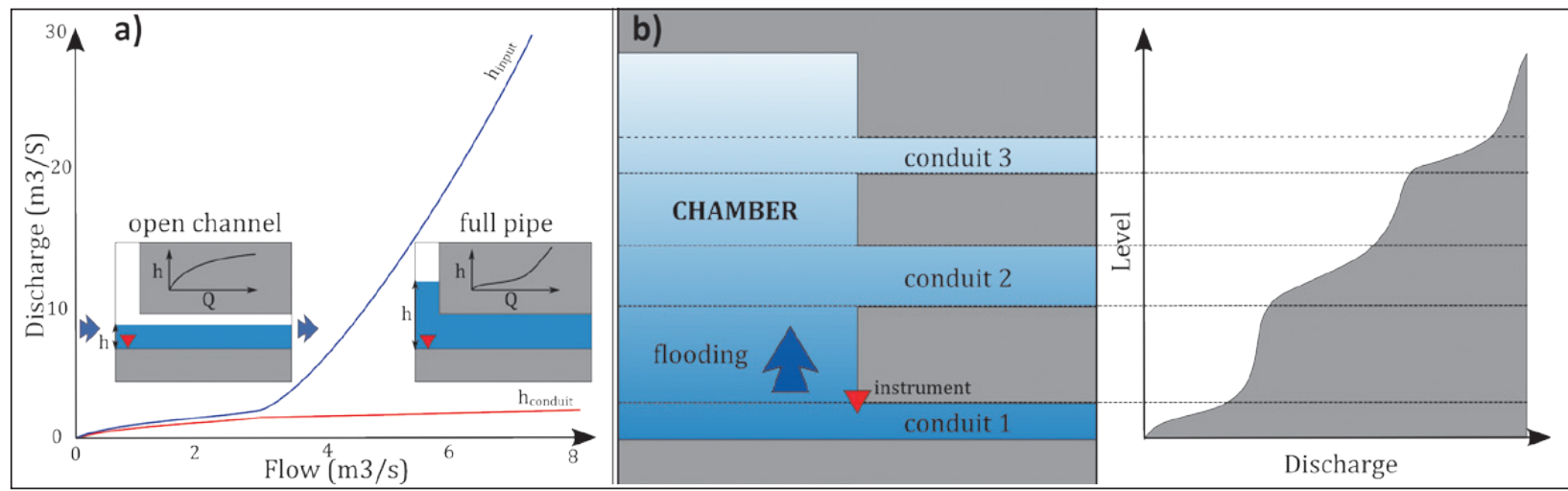

Fig. 5: a) Dependence of water level on the flow rate at the input (blue line) and inside (red line) of a $200 \mathrm{~m}$ long circular conduit with diameter $1.5 \mathrm{~m}$; the roughness factor is 0.05 . b) Inflections of a level hydrograph due to transitions between open channel and pressurised flow conditions in the base and overflow conduits (adapted from Gabrovšek et al. 2018). 
by the US Environmental Protection Agency (EPA 2014). SWMM is primarily aimed to simulate flow and transport in urban sewage systems. The model has found im- portant implications in modelling karst conduit networks (Peterson \& Wicks 2006; Chen \& Goldscheider 2014; Kaufmann et al. 2016; Gabrovšek et al. 2018, Gabrovšek

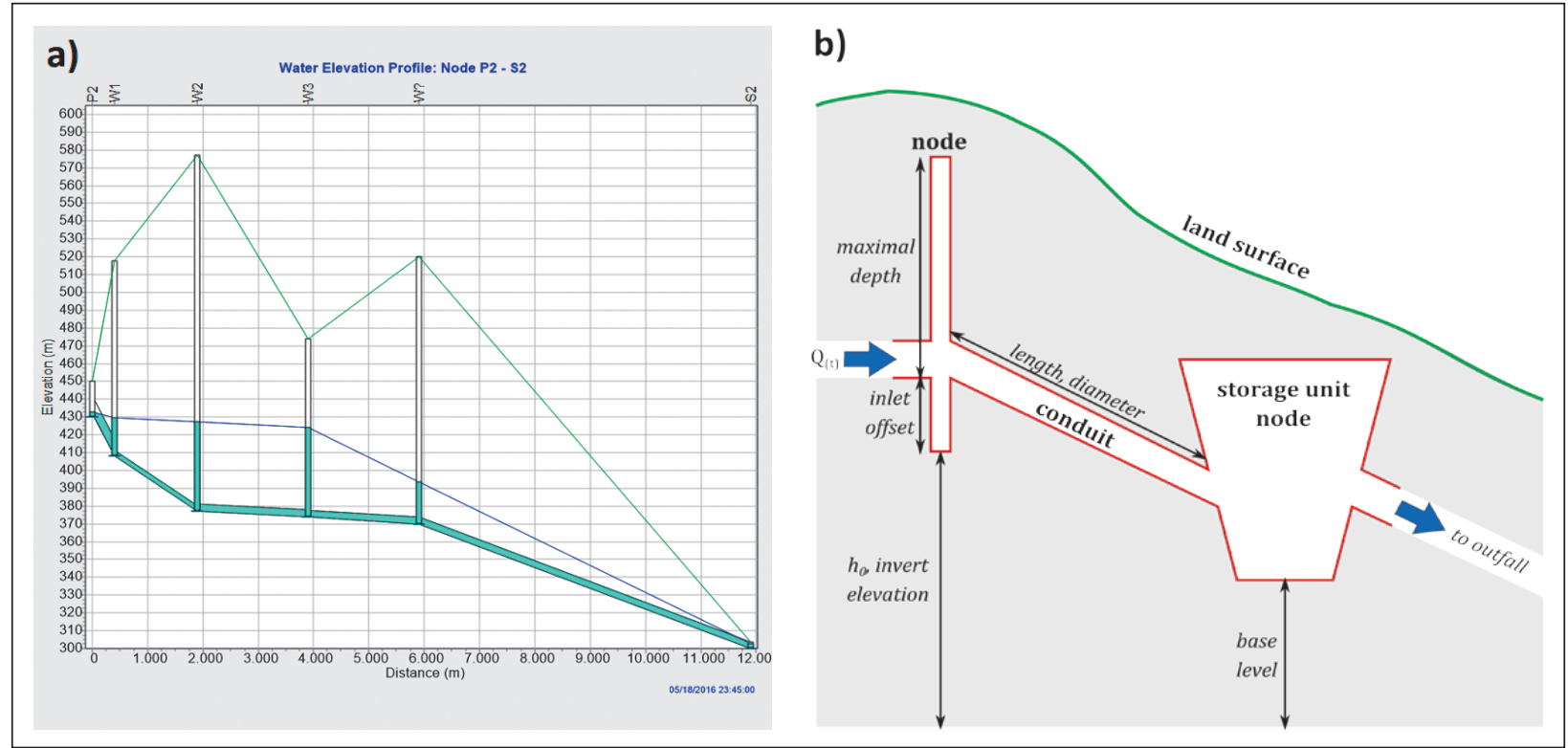

Fig. 6: Cross-section of a SWMM model. a) Longitudinal profile along a section of conduits and nodes. b) Schematic view of elements and parameters used (adapted from Gabrovšek et al. 2018).

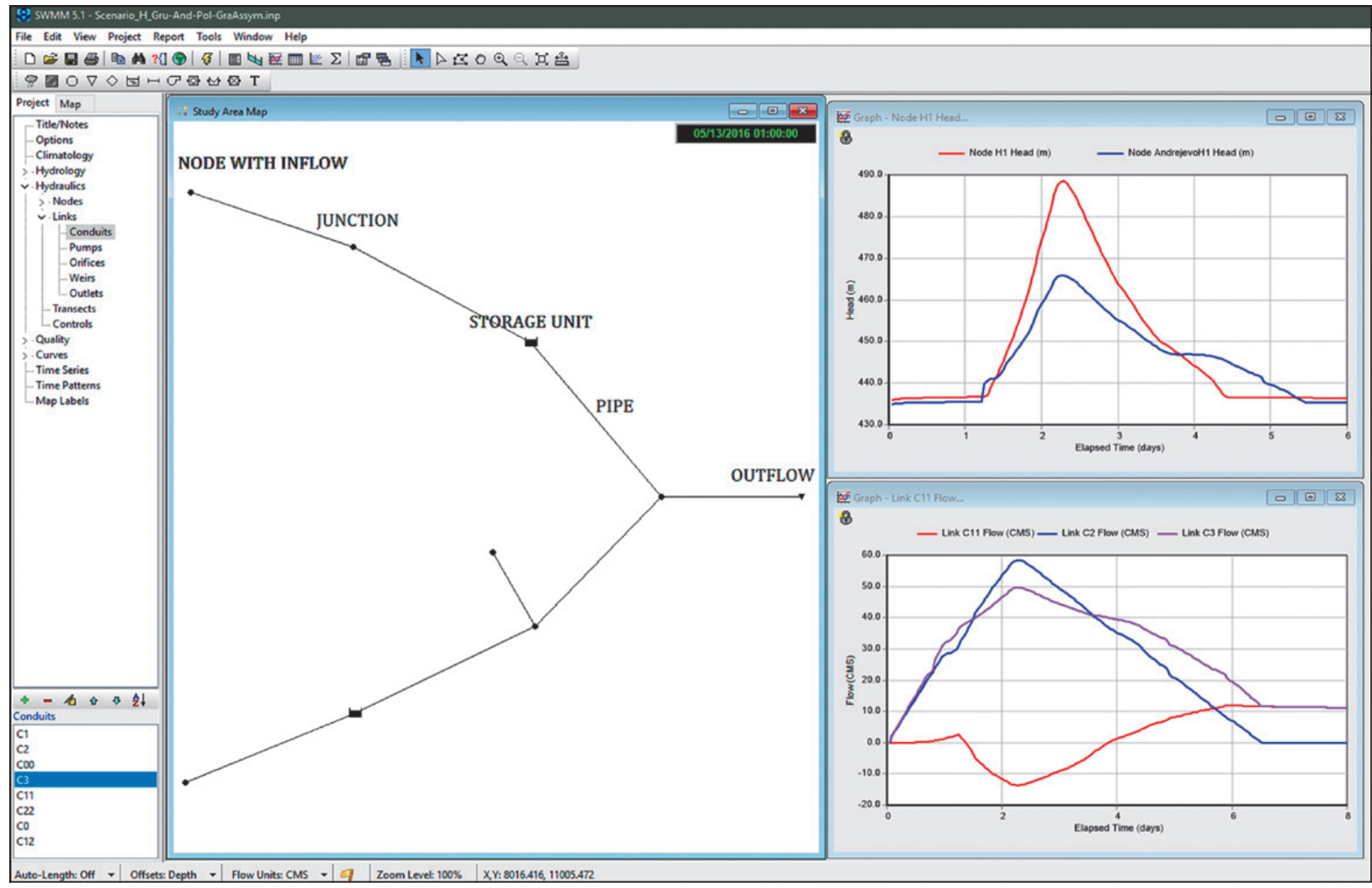

Fig. 7: Workspace of EPA SWMM with the model settings and plots of simulation results. 
et al. 2019). SWMM solves the Saint-Venant's equations (Dingman 2015; Rossman 2015) for an arbitrary distributed network of conduits and other hydraulic elements. To account for transition from an open channel to a full pipe flow, a surcharge algorithm is used (Rossman 2015).

In this work, the full solution of the Saint-Venant's equations was used. As SWMM considers only flow through conduits, its use is limited to specific conditions of flood response in conduit dominated karst aquifers. Therefore, a typical model in this work included a system of links, representing channels and conduits, whereas nodes and storage reservoirs represent junctions and chambers (Figs. $6 \& 7$ ). Only parts of the system between observation points were modelled. The aim was to use a minimal number of elements to capture the dynamics recorded by the observation network.

As the intention of modelling was to verify the validity of the conceptual models, the numerical models were parametrised in order to reproduce qualitatively the recorded hydrographs. Several authors have used successfully inversion algorithms to optimise hydraulic parameters (Chen \& Goldschheider 2014; Kaufman et al. 2016; Gabrovšek et al. 2018, Gabrovšek et al. 2019) and obtain numerically best fit according to selected criteria. In this case we have not done this, because even the initial geometry is poorly known, as only small part of the conduit system is surveyed.

The position and location of the nodes were determined from the cave survey data. The length of the conduits was based on straight line distances between two nodes. The position of overflow conduits were either estimated from the cave survey measurements or inferred from the inflections visible on the water level hydrographs. The initial estimates of conduit diameters were adapted manually to obtain a good qualitative fits. A constant Manning's roughness coefficient of 0.035 was used in all models. While the final models are great simplification of the conduit geometry in the field, they demonstrate the basic pattern of observed hydrological behaviour. The tables containing values of model parameters used within this study are given in Blatnik (2019).

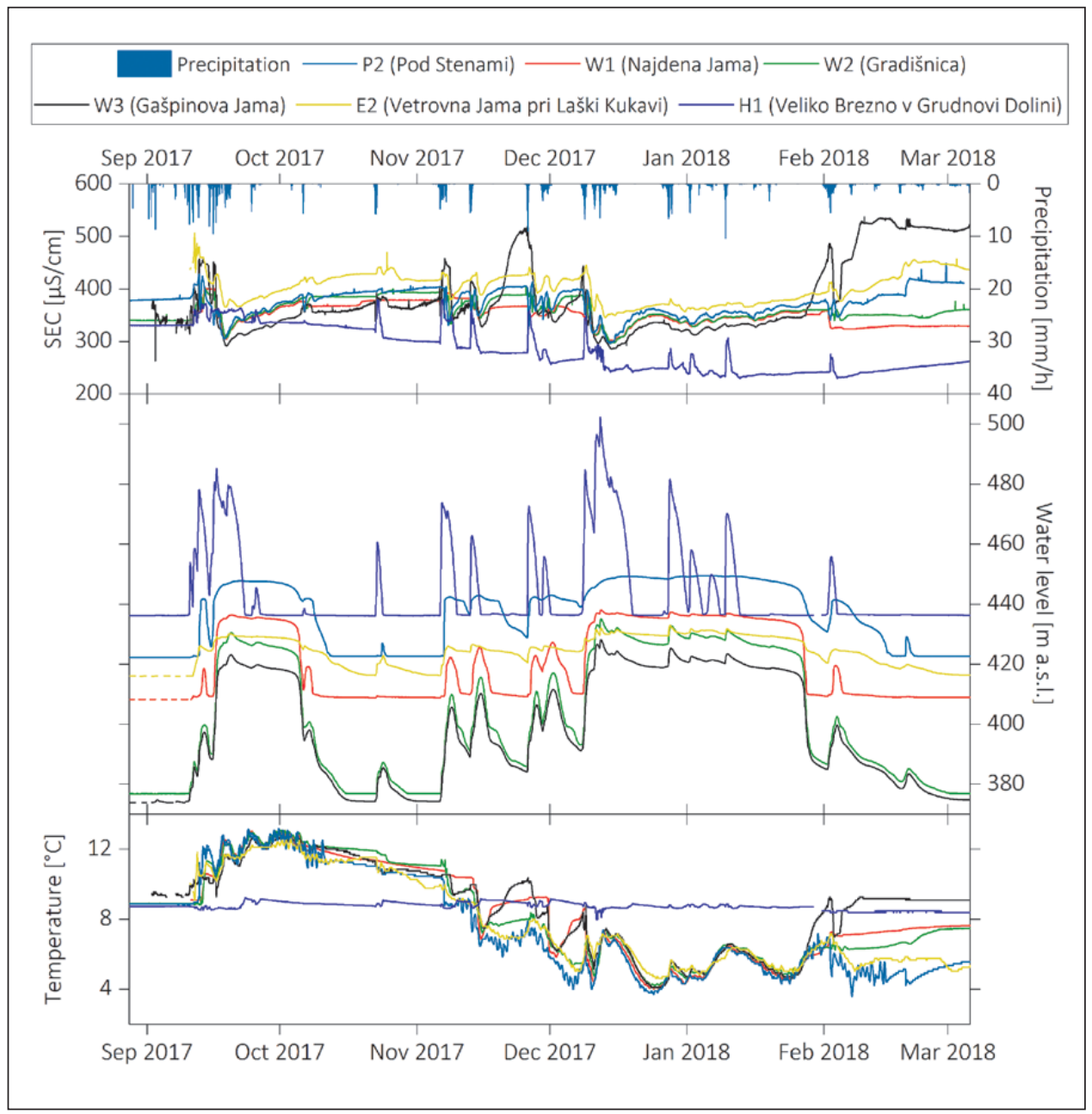

Fig. 8: Water level, SEC and temperature hydrographs for selected observation points between autumn 2017 and spring 2018. Dashed lines indicate periods where the water level was below the instrument. 


\section{RESULTS AND DISCUSSION}

\section{DATA OVERVIEW}

About $5000 \mathrm{~mm}$ of rain fell between January 2015 and May 2018, which correspond to a yearly average of about $1450 \mathrm{~mm}$ (ARSO 2019b). Fig. 8 shows records of several high water events for selected observation points. Tab. 2 presents extreme values, amplitudes and means of the parameters recorded at all measurement stations.

Besides many small scale events, there were 15 events when Planinsko Polje flooded. Such periods lasted from about a week up to three months (Fig. 8). During floods, the water level in the aquifer reaches its upper limit. For the subsystem located north of Planinsko Polje, the highest rise was observed in Gradišnica (W2) with $58 \mathrm{~m}$ above the instrument (Fig. 8). An even higher response $(66 \mathrm{~m})$ was recorded in the cave Veliko Brezno v Grudnovi Dolini (H1) on the southwestern side of the Idrija Fault Zone. For some of the studied caves, the entire amplitude of water level is unknown because the minimal water level is not accessible during low water periods (Tab. 2).

The average temperatures show some differences among the observation points. If the data-logger is located in a stream with permanent flow, the temperature record follows that of the Unica River. Such is the case of E2 (Vetrovna Jama pri Laški Kukavi). However, most of the instruments are positioned into a sump of stagnant water indicating the groundwater level, and record the ambient temperature in the cave during low flow conditions. These monitoring points become active flow paths only if water flows to a higher positioned overflow channel, when the temperature of the event water is recorded. Therefore, temperature hydrographs can indicate overflow phenomena.

Similar interpretations are valid for the SEC signal. A typical hydrograph shows an initial increase of SEC due to the arrival of old stored and calcite saturated water that is pushed by a piston effect. Conversely, a drop of SEC marks the arrival of fresh event water, followed by a gradual increase of more saturated autogenic component.

However, detailed analyses of temperature and SEC hydrographs are beyond the scope of this work and are not discussed further on.

In the following sections, an analysis on how each of the three above-defined hydrogeological subsystems responds to a flood event is presented. The main characteristics of hydrographs are shown and discussed. Then, conceptual hydrogeological models are built and validated numerically.

\section{SYSTEM RELATED TO THE EASTERN PONOR ZONE (P1): LOGARČEK (E1) AND VETROVNA JAMA PRI LAŠKI KUKAVI (E2)}

\section{Characteristics of recorded hydrographs}

Gabrovšek and Turk (2010) showed that Vetrovna Jama pri Laški Kukavi receives flow from the eastern ponors. A brief look at the data reveals a close correlation between

Tab. 2: List of all observed stations with the highest and lowest recorded water levels and their total amplitudes recorded during the observation period. The average temperatures and SEC are also shown. Note that in some locations there is no water during low water periods, so that the lowest water level and amplitude are unknown.

\begin{tabular}{|l|c|c|c|c|c|}
\hline Observation point & $\begin{array}{c}\text { Lowest water } \\
\text { level (m a.s.I.) }\end{array}$ & $\begin{array}{c}\text { Highest water } \\
\text { level (m a.s.I.) }\end{array}$ & $\begin{array}{c}\text { Water level } \\
\text { amplitude (m) }\end{array}$ & $\begin{array}{c}\text { Mean } \\
\text { temperature } \\
\left({ }^{\circ} \mathrm{C}\right)\end{array}$ & $\begin{array}{c}\text { Mean } \\
\text { SEC ( } \mu \mathrm{S} / \mathrm{cm})\end{array}$ \\
\hline P1: ponor Velike Loke & below 440.7 & 449.5 & $>7.7$ & 9.25 & $/$ \\
\hline E1: Logarček & 410.0 & 446.6 & 36.5 & 9.75 & 375 \\
\hline E2: Vetrovna Jama pri Laški Kukavi & 416.0 & 432.9 & 17.0 & 9.12 & 390 \\
\hline P2: ponor Požiralnik 1 Pod Stenami & 422.2 & 449.5 & 27.3 & 7.90 & 377 \\
\hline P3: ponor Požiralnik 1 v Škofovem Lomu & below 430.4 & 447.1 & $>16.7$ & $/$ & $/$ \\
\hline W1: Najdena Jama & 408.0 & 438.0 & 30.0 & 8.95 & 340 \\
\hline W2: Gradišnica & 376.8 & 435.0 & 58.2 & 8.65 & 350 \\
\hline W3: Gašpinova Jama & 373.9 & 428.0 & 54.1 & 9.25 & 365 \\
\hline H1: Veliko Brezno v Grudnovi Dolini & 436.3 & 502.3 & 66.0 & 8.50 & 300 \\
\hline H2: Andrejevo Brezno 1 & below 435.0 & 465.8 & $>30.8$ & 8.15 & $/$ \\
\hline
\end{tabular}


the ponor Velike Loke (P1) Logarček (E1) and Vetrovna Jama pri Laški Kukavi (E2), with water level fluctuations occurring almost simultaneously in E1 and E2 during flood events (Fig. 9). The cross-correlation coefficient of records at $\mathrm{E} 1$ and $\mathrm{E} 2$ reaches a value of 0.992 . As the eastern ponors are active most of the time, E1 and E2 show the longest period with increased water level among all observed caves.

There is a substantial difference between observation points in both caves. In E1, the instrument is fixed into a sump of stagnant water, which indicates the local groundwater level. This level can decrease for another 22 $\mathrm{m}$ during severe droughts periods, such as those in 2003 and 2016. At E2 the instrument is fixed into an inflowoutflow pool. The water level can also drop below the instrument during very dry periods, when the water level measurements in both caves are not comparable and the hydraulic connection between them is rather questionable.

During flood events, the rising discharge of the Unica River increases the recharge of eastern ponors and the response at E1 and E2. The first response is recorded at E1 and is followed by a response at E2. Once the level at E1 is about $15 \mathrm{~m}$ above that at E2, the level changes in both caves are occurring practically simultaneously (Fig. 9).

During high floods, the head difference between flooded Planinsko Polje (P1) and Logarček (E1) is only about $3 \mathrm{~m}$ at $1500 \mathrm{~m}$ of a straight-line distance between $\mathrm{P} 1$ and E1. At the same time, the head difference between Logarček (E1) and Vetrovna Jama pri Laški Kukavi (E2) is about $15 \mathrm{~m}$ along a comparable distance. This indicates a higher transmissivity in proximity of the polje's eastern border, than between E1 and E2.

The hydrographs recorded at both stations show inflections that occur at the same water level during all high water events. At $\mathrm{E} 1$ the most evident inflection point is at $439 \mathrm{~m}$ a.s.l. This matches the position of a large overflow passage called Skalni Rov (Fig. 4).

Temperature and SEC hydrographs also show a perfect correlation during active overflow, supporting the assumption of the same flow between both caves

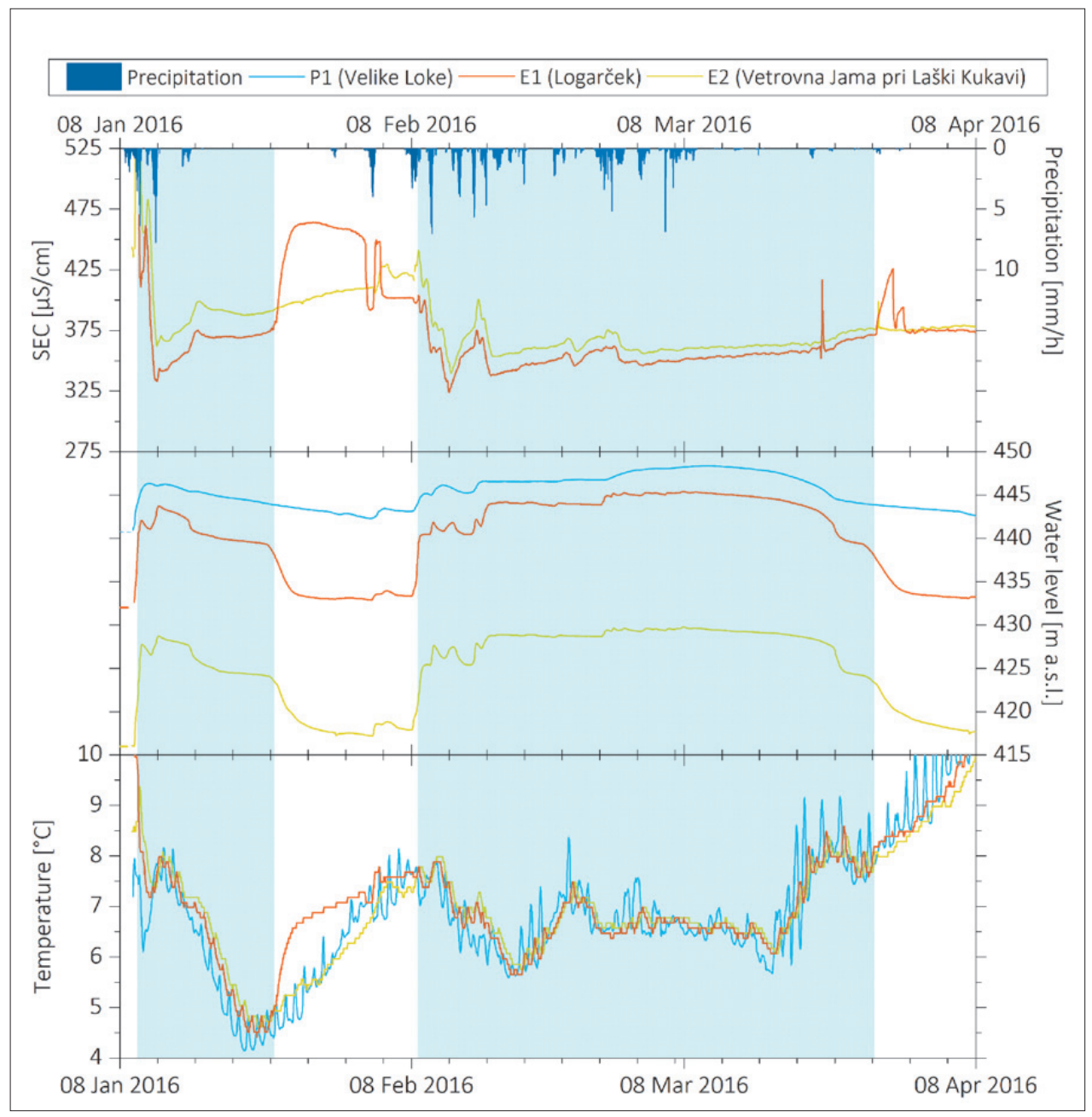

Fig. 9: Hydrographs of water level, temperature, and SEC show a good correlation between E1 (Logarček) and E2 (Vetrovna Jama pri Laški Kukavi) in February and March 2017. Periods with active overflow through Bukovčev and Skalni Rov are marked with blue belts. 
(Fig. 9, blue regions). Analysis of time lags between diurnal oscillations of temperature in both caves showed transit times varying between $7 \mathrm{~h}$ and $12 \mathrm{~h}$.

When the water level drops below the overflow level, the flow from the polje must be guided by conduits below the position of the instrument at E1. Therefore, the temperature and SEC become strongly influenced by the local infiltration of water from the surface (white regions in Fig. 9). Fig. 9 shows the winter situation, when the water percolating through the massif is warmer than the concentrated recharge arriving from the polje. At the same time, an increase of SEC is recorded, most probably due to washed salt from the nearby motorway.

Although the level hydrographs show similar dynamics for both caves, a detailed look reveals important differences. Fig. 10a shows correlation plots between the heads at E1 and E2 for several events. The rise and recession of the curve are clearly different and present a hysteresis. At the beginning of the event, the rise of water level is faster at E1, which is expected, as the head differ- ence between the two observation points increases with increasing flow. When the level at E1 reaches the elevation of about $439 \mathrm{~m}$ a.s.l., the activation of the overflow allows an additional outflow from E1 towards E2. This results in slow increase at E1, compared to a fast increase at E2. After that, the rise in both caves is similar. During recession, the heads drop at both points do not experience large deviations.

\section{Conceptual and numerical model}

To understand the hys teresis, several SWMM models were implemented and tested. The most plausible interpretation is presented in Fig. 11, and consists of three nodes connected by several channels. P1 represents Planinsko Polje, E1 and E2 are the caves, connected to the polje by the channels $\mathrm{C} 1$ and $\mathrm{C} 2$. In addition, E1 and E2 are connected with a higher positioned channel C3 that represents the overflow passage. Downstream from E2, the channel C4 limits the outflow.

The model shows three distinct phases observed in all events (Fig. 11):
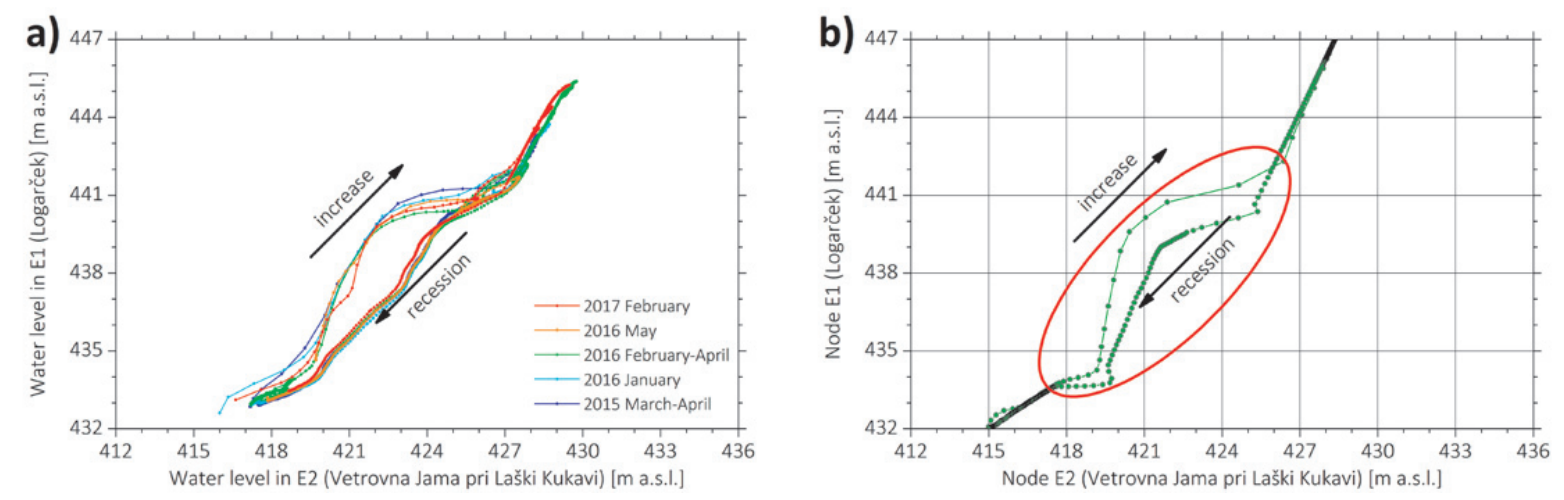

Fig. 10: Correlation between heads at observation points in E1 (Logarček) and E2 (Vetrovna Jama pri Laški Kukavi): a) measurements during several high water events; b) results of a modelled event, the hysteresis between both rise and recession indicates storage between the two observation points.

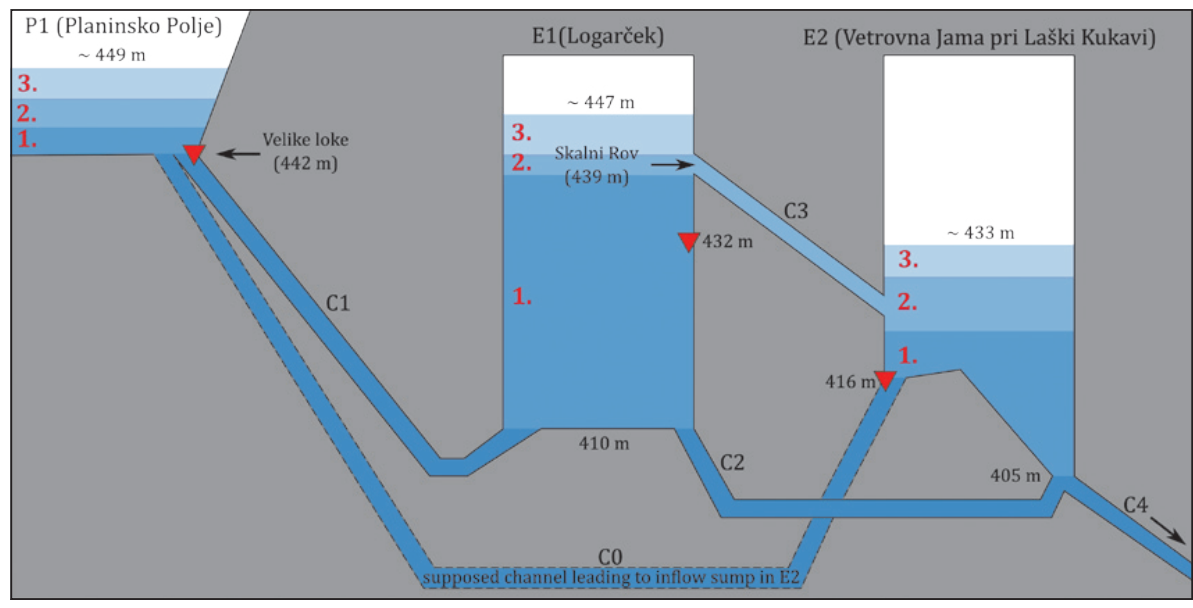

Fig. 11: Inferred distribution of conduits connecting Planinsko Polje with caves E1 (Logarček) and E2 (Vetrovna Jama pri Laški Kukavi). The higher positioned inflow sump in E2 is most likely discharged directly from Planinsko Polje, whereas the lower could be connected to E1. Red triangles indicate positions of instruments. 
1. When E1 and E2 are connected only by $\mathrm{C} 2$, the head at both nodes and the difference between them increases according to the increasing recharge.

2. When the water at $\mathrm{E} 1$ reaches the position of the overflow (C3), the increasing recharge is conveyed as an open channel flow through $\mathrm{C} 3$, causing fast rise of the head at E2. The head difference between E1 and E2 drops until the water level at E2 reaches the position of the overflow.

3. From then on, both heads rise at similar rate until their maximum. The rise is controlled by the resistance of the channel C4.

Until the position of the overflow, the recession follows the same path as the rise. Then the head drop at E2 is not as abrupt as during the rising stage, which leads to an offset between the rising and the recession part (Figs. 10a \& 10b). This may be caused by the storage in C3 (Fig. 11), which prolongs the recharge to $\mathrm{E} 2$ during the recession and keeps its water level high. In fact, the hysteresis in the model could only be reproduced if $\mathrm{C} 3$ presents a considerable storage.

Conduit C0 in Fig. 11 presents recharge to E2 other than that arriving from E1. Such recharge is evident during low flow situation, but does not influence the characteristics of flood events discussed here.

\section{SYSTEM CONNECTED TO THE NORTHERN}

PONOR ZONE (P2-P3): NAJDENA JAMA (W1), GRADIŠNICA (W2) AND GAŠPINOVA JAMA (W3) When the outflow capacity of the eastern group of ponors is surpassed, the main flow of Unica continues towards the northern border of Planinsko Polje. The northern ponors can be grouped into two zones: Pod Stenami (P2) and Škofov Lom (P3). Previous investigations made by Gabrovšek and Turk (2010) found almost simultaneous water level oscillations in Gradišnica (W2) and Gašpinova Jama (W3) that precede the reaction in Najdena Jama (W1), which is located much closer to the ponors. However, they did not monitor the reaction of the ponors, which prevented to draw any conclusion on how the northern ponors are connected with the underground network.

\section{Characteristics of the hydrographs}

Fig. 12 shows a typical high water event from spring 2018. Level hydrographs at all points show good correlation with flow hydrograph of the Unica River. Fig. 13 shows the initial phase of the same event as recorded at P2, W1, W2, W3 and the Unica discharge. The response at W2 and W3 precede all others, which indicates their hydraulic connection to important inflows other than the northern ponor group. Blue region in Fig. 13 marks the activation of ponor $\mathrm{P} 2$, followed by a steep rise of the level at W2. Arrival of event water from the polje is also recorded by the temperature hydrograph at W2 and W3.

Fig. 14 shows the rising limb of the level hydrograph at W2 for several high water events. The hydrographs show several inflections at different levels. However, most curves show an inflection at the level $400 \mathrm{~m}$ a.s.l., where the overflow through Putickova Dvorana to Šerkov Rov (see Fig. 4) becomes active.

Despite its proximity to the ponor zone Pod Stenami (P2), the response of $\mathrm{W} 1$ to the flood is unexpectedly delayed (Figs. 12 \& 13). This suggests that W1 could

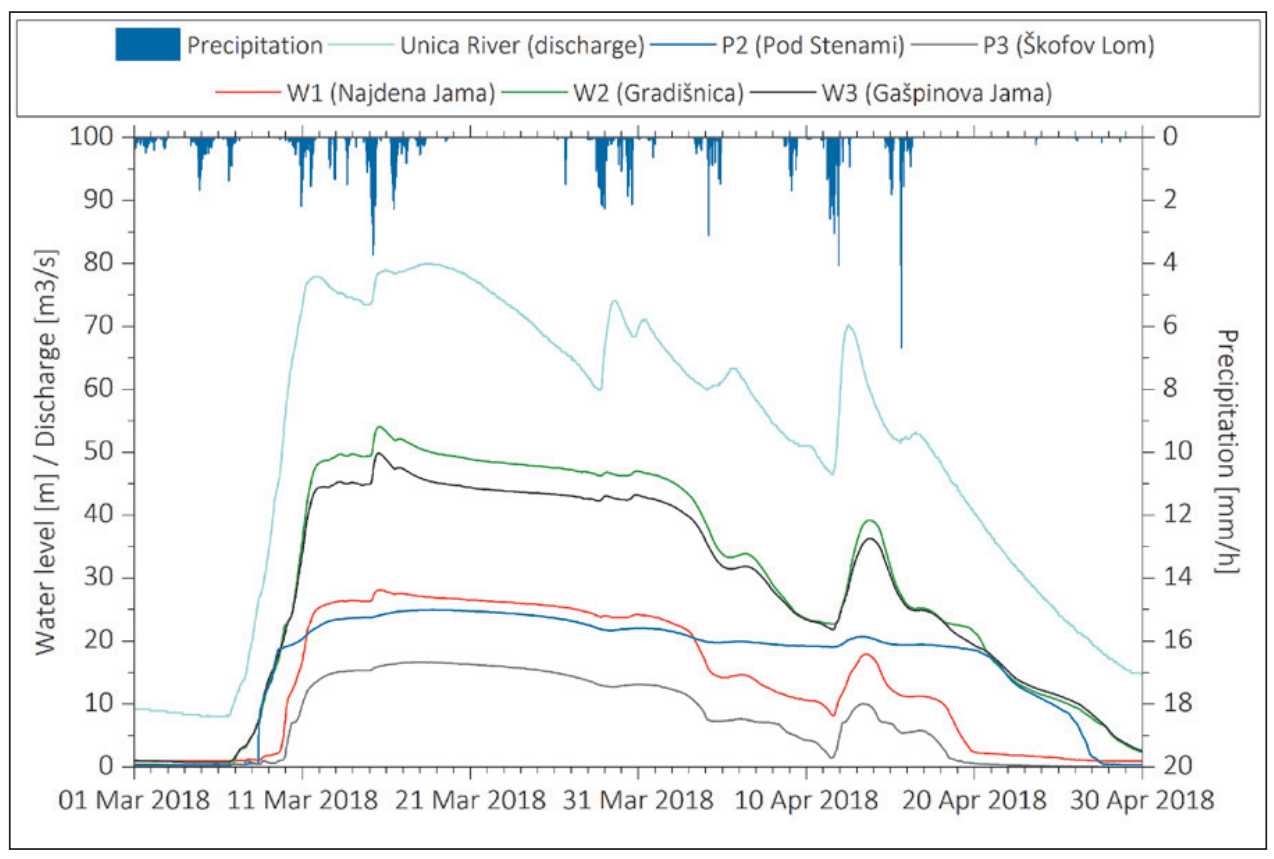

Fig. 12: A high water event recorded at the northern ponors and related caves. 
be recharged by another ponor zone. This assumption was confirmed by adding another observation point at P3, the ponor zone located in Škofov Lom (Figs. 4, 12 \& 15). Because the main flow of Unica is connected to this ponor via higher positioned channel (Fig. 15), the ponor P3 becomes active only after the level in the Unica River rises high enough due to the back-flooding at ponor zone Pod Stenami (P2) (Fig. 12). The time difference between the onset of events at $\mathrm{P} 2$ and $\mathrm{P} 3$ is controlled by the event intensity and varies between 2 and over 10 hours. The activation of P3 brings inflow into Najdena Jama (W1), where the water level reacts vigorously. Similarly as in W2, the level at W1 must reach the position of an overflow channel to record the temperature of the event water. The activation of $\mathrm{P} 3$ and $\mathrm{W} 1$ is also recorded at W2 and W3, with an additional increase of water level and diurnal character of temperature hydrographs (Figs. 8 \& 13).

The question remains, why does the flow from P2 bypasses Najdena Jama (W1) even if both are located not more than $500 \mathrm{~m}$ apart from each other? As the area is located at the border of the Idrija Fault Zone, the most
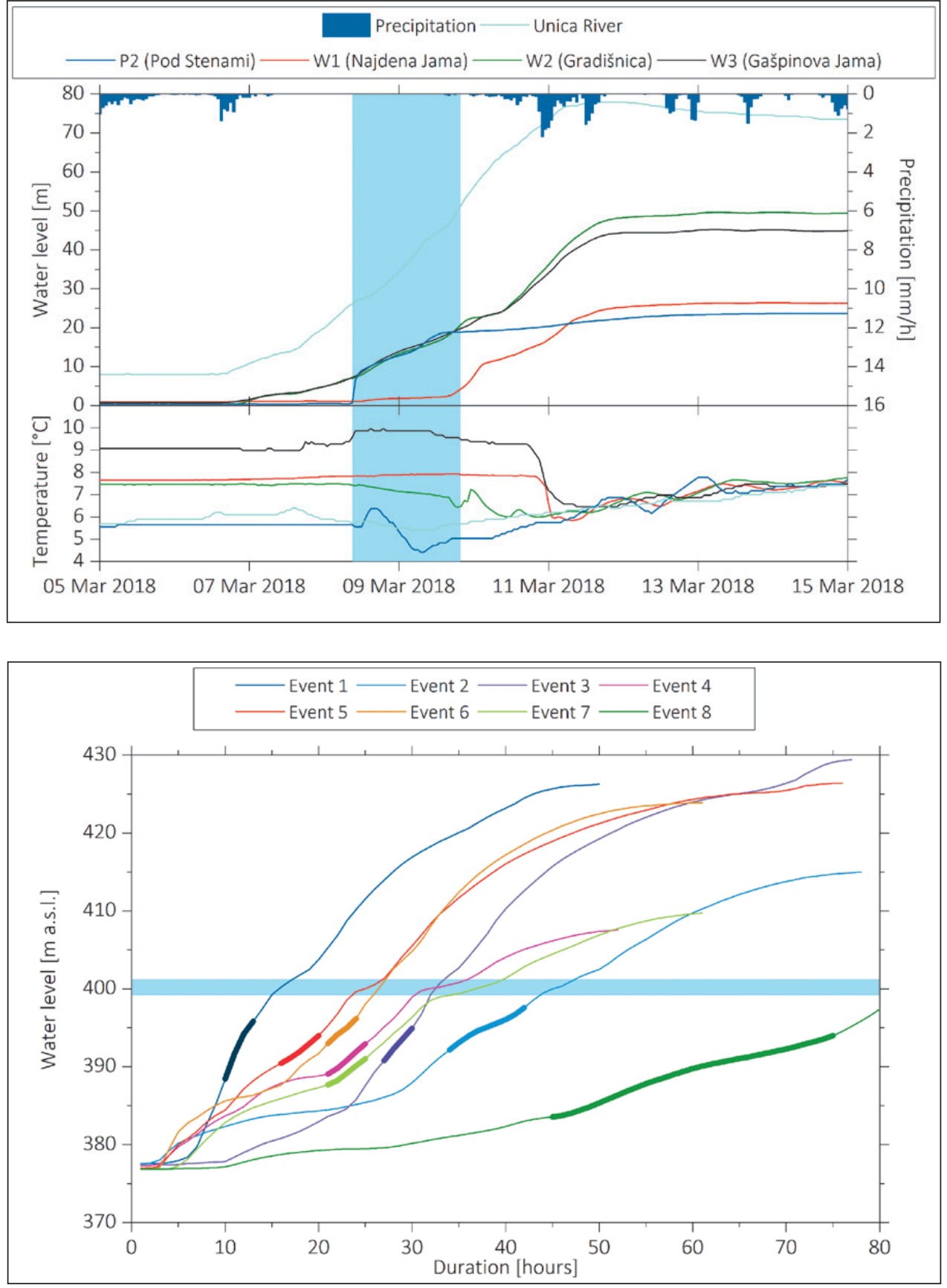

Fig. 13: Onset of a high water event as recorded in $\mathrm{P} 2$, W1, W2 and W3. The blue belt marks the activation of northern ponors (P2) and related increase of water level at W2 and W3. Note the delayed reaction at $W 1$.

Fig. 14: Initial increase of the water level at W2 (Gradišnica) for several high water events. The thicker part of the curves show the periods where the water level increase at $P 2$. The blue belt marks the inflection caused by the overflow towards Šerkov Rov. 
plausible (yet unconfirmed) answer is the presence of a hydrogeological barrier caused by one or several structural elements that would divert the flow (Fig. 15). Similar observations have been already made by Šušteršič (2006) in some other parts of the Ljubljanica Recharge area and would tend to support this assumption.

The cave Gašpinova Jama (W3) shows a very similar behaviour to Gradišnica (W2) (Figs. 8 \& 16). The water level rise and drop almost synchronously in both caves, which indicate a high hydraulic connectivity between the two locations. This is also confirmed when computing cross-correlation between the two caves, with a value reaching 0.999 .

During high water events in Planinsko Polje, the hydraulic head difference between P2-P3 and W1 is about $10 \mathrm{~m}$ along a $500 \mathrm{~m}$ straight line distance. From there to $\mathrm{W} 2$, the stage difference is only about $3 \mathrm{~m}$ at $2000 \mathrm{~m}$ and from W2 to W3 about $5 \mathrm{~m}$ at $1500 \mathrm{~m}$ of straight line distance. This indicates a zone of lower transmissivity close to the border of Planinsko Polje and higher further from W1 to W3.

The hydrographs show at all locations typical inflections at certain levels during all high water events (Figs. $8,12,13 \& 14)$. Such is the one visible at the level of 400 m a.s.l. in Gradišnica (W2) that is highlighted in Fig. 14. This inflection matches with the positon of the passage named Šerkov Rov (Fig. 4), which most likely behaves as an overflow towards Gašpinova Jama (W3). Inflections points are also visible at W3 (Fig. 18a). In the complex system of W1, the inflection point indicates the probable presence of an overflow at $420 \mathrm{~m}$ a.s.l. Fig. 16 shows the rate of change of head at $\mathrm{W} 1, \mathrm{~W} 2$ and $\mathrm{W} 3$ depending on the water level for all large high water events. The red lines represent a moving average of 30 points and show evidence of inflections in all curves. As an example, one can clearly see several local minima of rise/drop at particular head values. Some of these can be linked to known overflow levels such as the one in Gradišnica (W2), some others are not yet reported such as the one at $420 \mathrm{~m}$ a.s.l. recorded in W3 and (probably) related minima between 425 to $430 \mathrm{~m}$ a.s.l. at W2.

\section{Conceptual and numerical models of the subsystem}

The observations discussed above can now be summarised into a conceptual hydraulic model (Fig. 17) and tested numerically. The node, representing the polje has two outflows, representing the ponor zones $\mathrm{P} 2$ and $\mathrm{P} 3$. $\mathrm{P} 2$ is directly connected to $\mathrm{W} 2$ and further to W3. P3

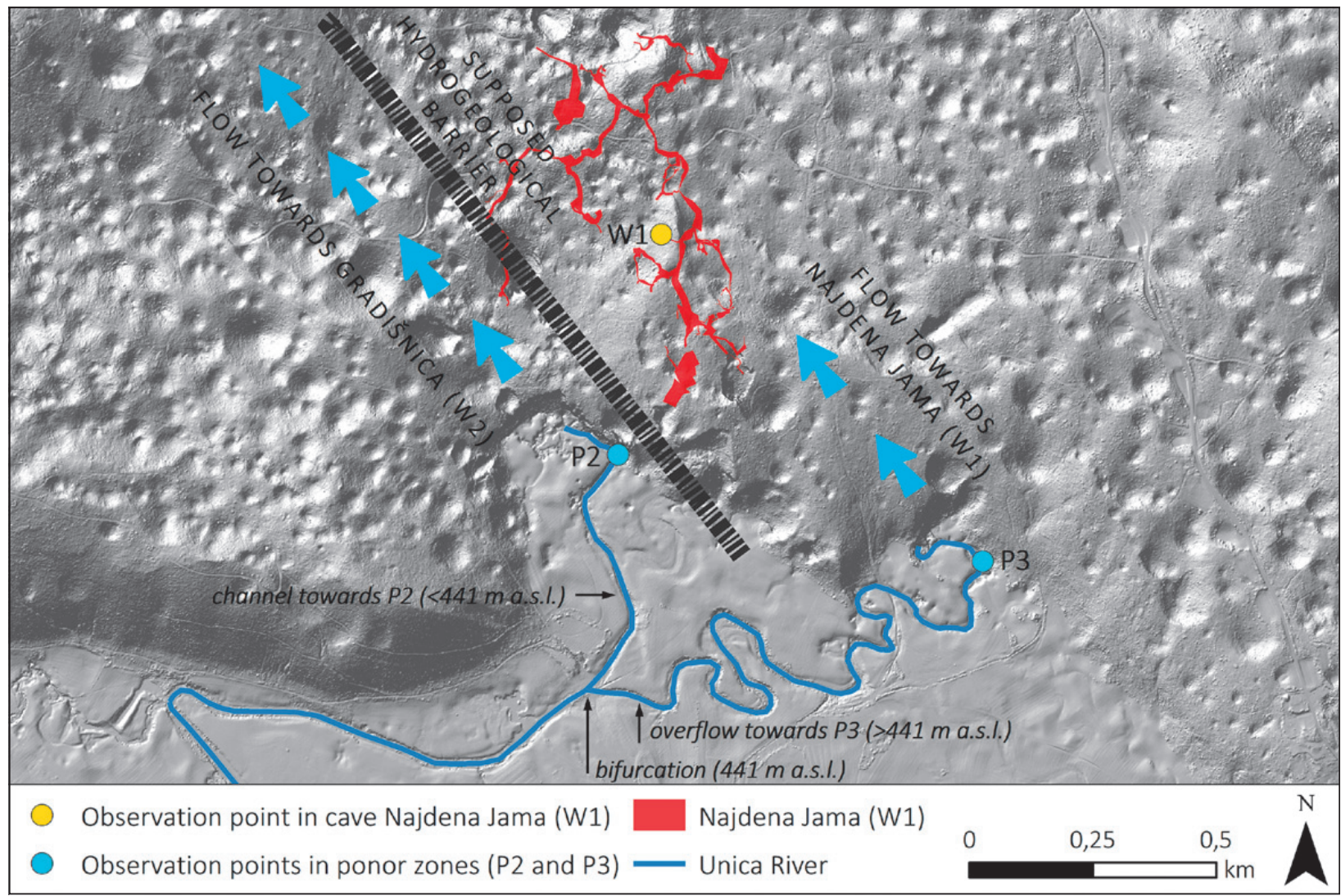

Fig. 15: Detailed map of the northern ponor zone with instruments at Pod Stenami (P2), Škofov Lom (P3) and observation points in Najdena Jama (W1) (DEM data from ARSO 2019c; Cave data from Cave Register 2019). 


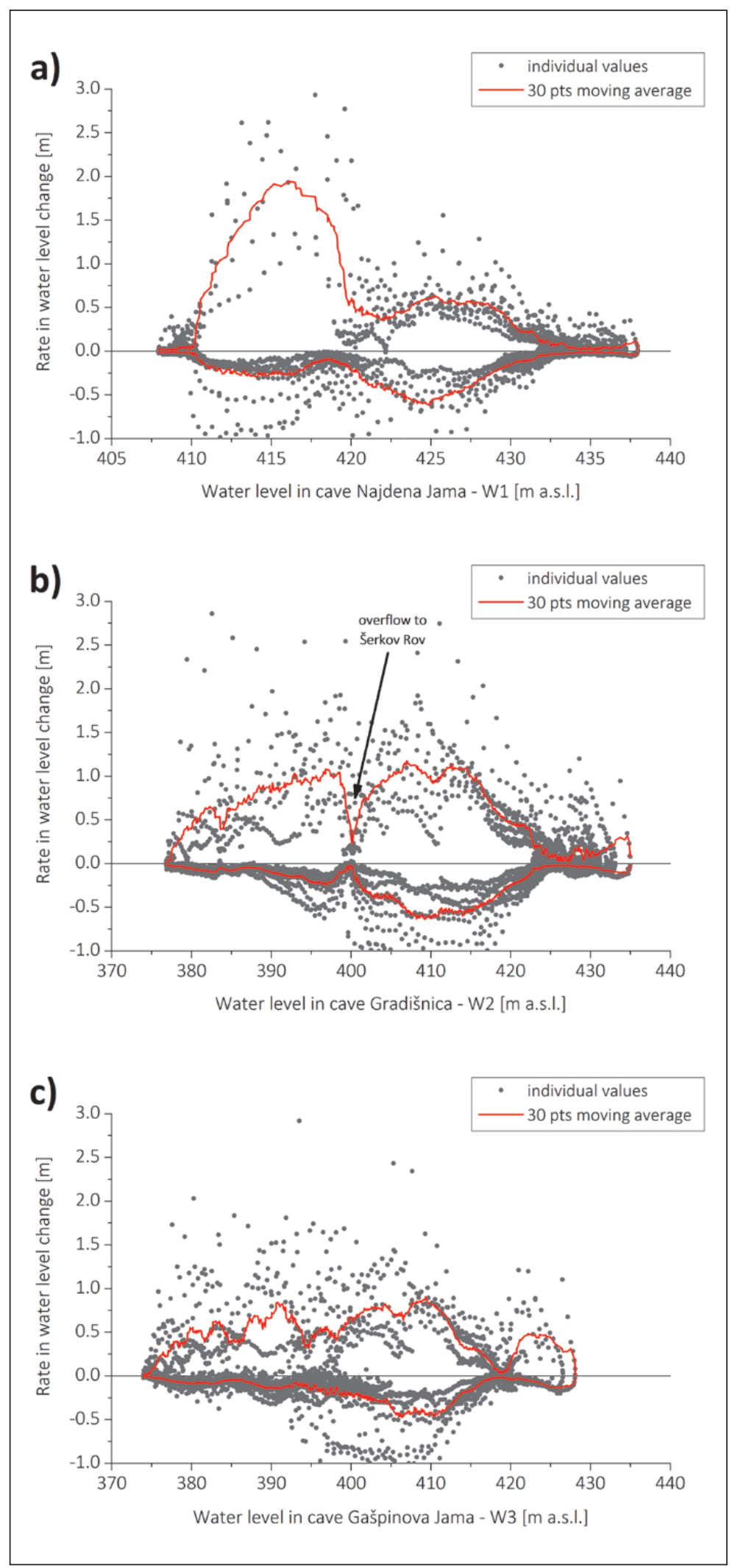

Fig. 16: Rate of water level increase and decrease as a function of the absolute water level at: (a) W1 (Najdena Jama), (b) W2 (Gradišnica) and (c) W3 (Gašpinova Jama). is positioned $2 \mathrm{~m}$ above $\mathrm{P} 2$ and is connected to $\mathrm{W} 1$, and further to W2-W3. W1 and W2 are connected with an additional higher positioned overflow channel (C4) that was inferred from the hydrographs (Figs. 13 and 16a). This came out to be a minimal set of elements that can simulate the observations. Fig. 18 shows the recorded level hydrographs from May 2016 and the simulated hydrographs obtained in SWMM.

The sequence of events during a typical flood can be listed as follows (Fig. 18):

1. A first response to the high water event is registered at W2-W3. This precedes the activation of the northern ponors and indicates a probable connection to the eastern ponor zone (P1) or to the Hrušica Plateau $(\mathrm{H} 1-\mathrm{H} 2)$ or to another recharge area than Planinsko Polje. This connection is represented by an additional channel (C0) on Fig. 17. This channel was not part of the SWMM model.

2. The activation of the northern ponor zone begins in the region of $\mathrm{P} 2$ and causes a fast increase of the water level at W2-W3.

3. The limited resistance of conduits between P2 and W2-W3 causes the back-flooding of $\mathrm{P} 2$ and a rise of water level in the polje. This activates a higher positioned channel of the Unica River connected to P3 (Figs. $12 \& 15)$, which is followed by a strong response at $\mathrm{W} 1$ and an additional rise of water level at W2 and W3. Additional inflection points caused by overflows are recorded in those caves (Figs. 12, 13, 14 \& 16).

4. The water reaches the highest level in the system, which remains relatively stagnant until the polje is flooded.

The recession shows a reversed behaviour (Fig. 18). P3 is the first ponor that is deactivated and therefore the water level drops first in W1 (Fig. 12). At this time, also levels at $\mathrm{W} 2$ and $\mathrm{W} 3$ show a fast recession. After the level reaches its minimum in $\mathrm{W} 1$, the recession in W2 and W3 continues slowly towards low water stage due to the inflow from the other ponor zones (P2 and P1) (Fig. 12).

During low water periods, all observation points are represented by sumps with stagnant water and water temperature is mainly influenced by the ambient temperatures in caves. 


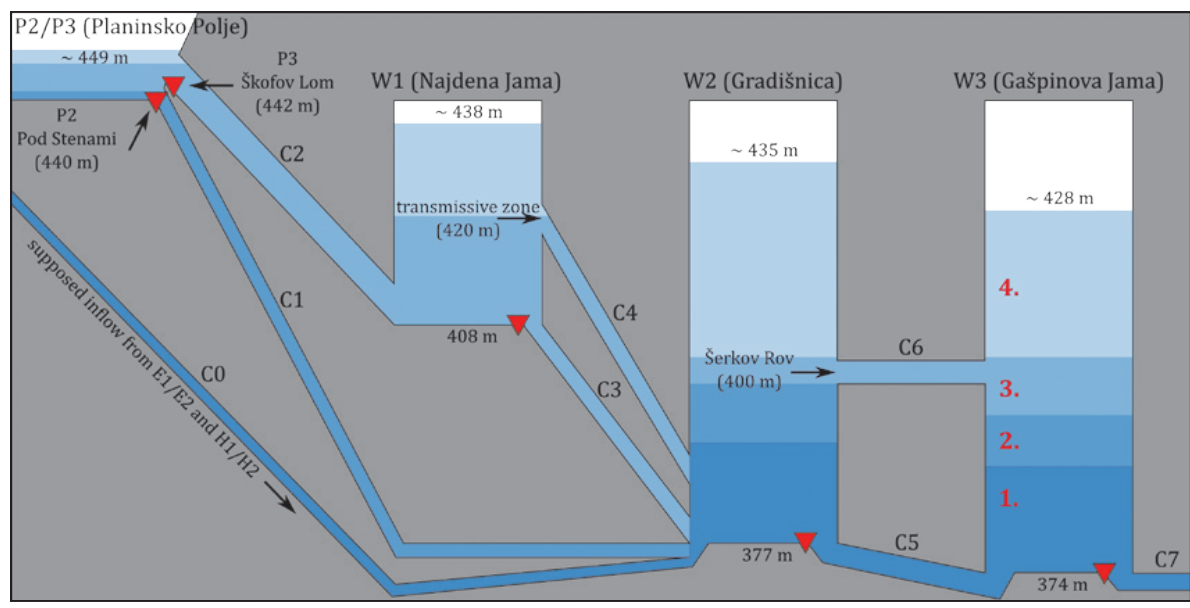

Fig. 17: Inferred conduit-based model of the subsystem between the northern ponors of Planinsko Polje (P2 and P3) and W3 (Gašpinova Jama). Numbers and colours denote different phases of water level response also marked on Fig. 18 . The position of the data loggers is shown by red triangles.
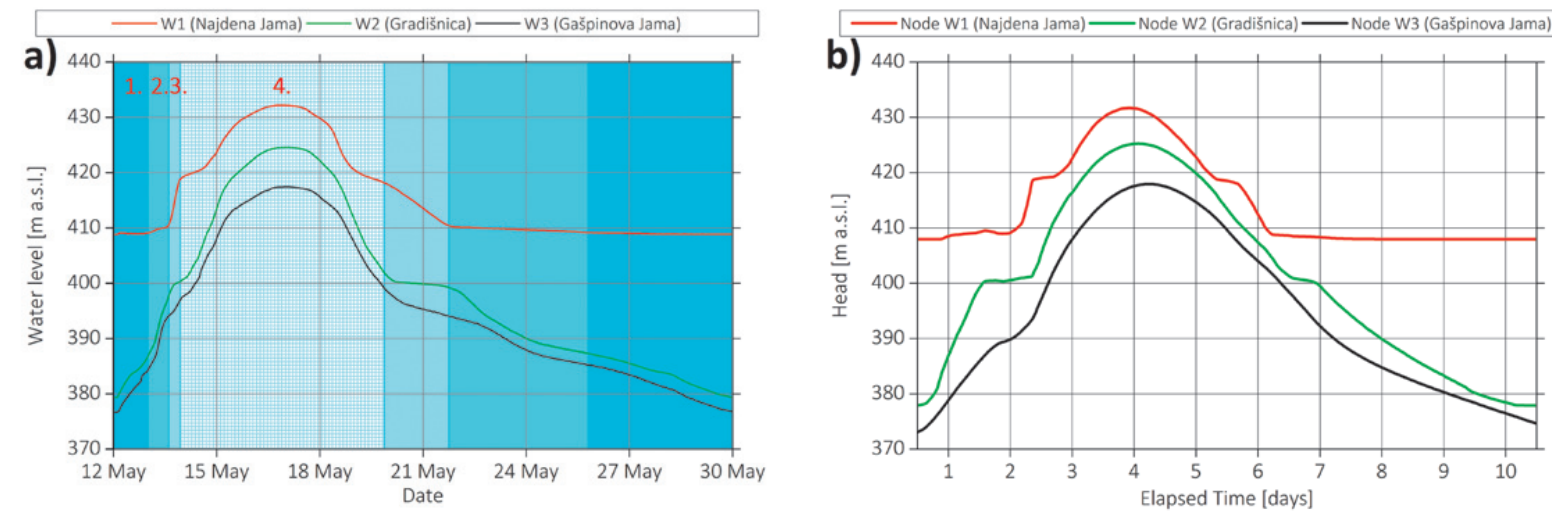

Fig. 18: a) Recorded water level hydrograph of an event from May 2016; b) Simulated water level hydrograph at W1, W2 and W3.

SYSTEM RECHARGED FROM THE HRUŠICA

PLATEAU: VELIKO BREZNO V GRUDNOVI

DOLINI (H1) AND ANDREJEVO BREZNO 1 (H2)

The caves H1 (Veliko Brezno v Grudnovi Dolini) and H2 (Andrejevo Brezno 1) are located on the southwestern (upstream, compared to the caves discussed before) side of the Idrija Fault Zone (IFZ) and not known to be recharged from any of the ponor zones discussed previously (Fig. 2). This subsystem is assumed to primarily receive autogenic recharge from the Hrušica Plateau, and probably drain an allogenic component from the recharge area of the Hotenjka River (Gospodarič \& Habič 1976). This study is the first to investigate the hydraulic behaviour of both caves and attempts to explain it in light of the regional hydrogeological context. During low water periods, there is no active flow in both caves: the water level is stagnant at $436 \mathrm{~m}$ a.s.l. in $\mathrm{H} 1$ whereas $\mathrm{H} 2$ is dry. During extreme flood events such as the one that occurred in September 2010, the water level in $\mathrm{H} 1$ rises for more than $70 \mathrm{~m}$ and the cave becomes an intermittent spring (Mihevc 2014) whereas only the lower parts of H2 are flooded (Fig. 4).
Besides understanding the local hydrogeological situation, several other objectives were targeted by monitoring these two caves, in order to answer the following questions: - is the area hydrogeologicaly related to the overflow springs and estavelles located at the northwestern border of Planinsko Polje, below the village of Grčarevec?

- can we draw any conclusions on the transmissivity of the Idrija Fault Zone based on the observations in these two caves?

- how is the region related to the aquifer located north of Planinsko Polje?

\section{Characteristics of recorded hydrographs}

Fig. 19 shows a level hydrograph including a high water event as recorded at $\mathrm{H} 1$ and $\mathrm{H} 2$. Hydrographs of P2 and W2 are added for a broader picture of the regional hydrogeological context.

The characteristics of the level hydrographs at $\mathrm{H} 1$ and $\mathrm{H} 2$ can be summarised into the following:

- The response at H1 and H2 is fast and short (Fig. 19). For all events, the rise in $\mathrm{H} 1$ precedes the one in $\mathrm{H} 2$. In addition, the recession in $\mathrm{H} 1$ is generally faster. 
- Both caves show a rapid transition from fast recession to a stable level (Fig. 19). The level hydrograph look incomplete, like they would only present the peak of a complete hydrographs. This is expected at $\mathrm{H} 2$ where only peaks, when water reaches the instrument, are recorded and the almost stable "level" value is the atmospheric pressure. However, at $\mathrm{H} 1$ a very stable water level is reached. A plausible explanation would be that the region of $\mathrm{H} 1$ is back-flooded from the downward region with a lower base level. While this lower region experiences the complete event rise and recession, only peaks are recorded at $\mathrm{H} 1$. The stable position of $\mathrm{H} 1$ at low water levels would be hard to sustain during extended dry periods if this system would be completely decoupled from the rest (e.g., the base level in $\mathrm{H} 1$ would present perched water in the siphon). A more reasonable explanation involves a flow barrier below the level of $436 \mathrm{~m}$ a.s.l. and a highly transmissive zone above this level, which allows free flow from the area of $\mathrm{H} 1$ towards the region of W2 and W3 (Figs. 23 \& 24). This conceptual model is discussed in the following subsection.

\section{A conceptual model with a hydrogeological barrier}

To elucidate the reasoning given above, Fig. 20 shows a conceptual cross-section of a karst massif at different hydrological conditions. Three caves at different positions are shown: the Cave 1 is located at the upstream side of a flow barrier (analogy to H1). The Cave 2 has no access to the base level, but is reached by floods (analogy to $\mathrm{H} 2$ ). Finally, the Cave 3 is an analogue to W2 and reaches the position of the base level. The red triangles indicate the position of hypothetical instruments. A schematic level hydrograph is drawn for each cave. Red and green dots correspond to the presented situations during rising (red) and recession (green) stage on the flood event. Under low flow situation, the constant water level in Cave 1 is constrained by the barrier. The Cave 2 records the air pressure and Cave 3 the low groundwater level (Fig. 20a). At the onset of the event, both Cave 1 and 2 still record no hydraulic response, as water flows freely over the barrier and the instrument in Cave 2 is still above the water level. In opposite, the water level rises in Cave 3 due to resistance of the conduits downstream from Cave 3 (Fig. 20b). Fig. 20c shows the hydrogeological situation at peak levels in all caves. When backflooding from the downstream region (region of Cave 3) reaches top of the barrier, the water rises above the instrument in Cave 1 and reaches also the instrument in Cave 2. During recession, Cave 2 gets dry while the stage in Cave 1 stays constant as soon as the water on the downstream side of the barrier drops below the barrier level. Cave 3 is the only one that records the complete hydrograph.

\section{Relation of the subsystem with Planinsko Polje}

When the water level in $\mathrm{H} 1$ and $\mathrm{H} 2$ is above Planinsko Polje (Fig. 19) a set of springs is activated below the village of Grčarevec at the polje north-western border. The highest springs are located about $25 \mathrm{~m}$ above the poljes surface (Fig. 21b). The lowest springs can also act as estavelles: they become ponors when the polje is still flooded whereas the water level in the region $\mathrm{H} 1$ and $\mathrm{H} 2$ already drops. This situation is visible on Fig. 22; the recession in $\mathrm{H} 1$ is completed, while the polje is still

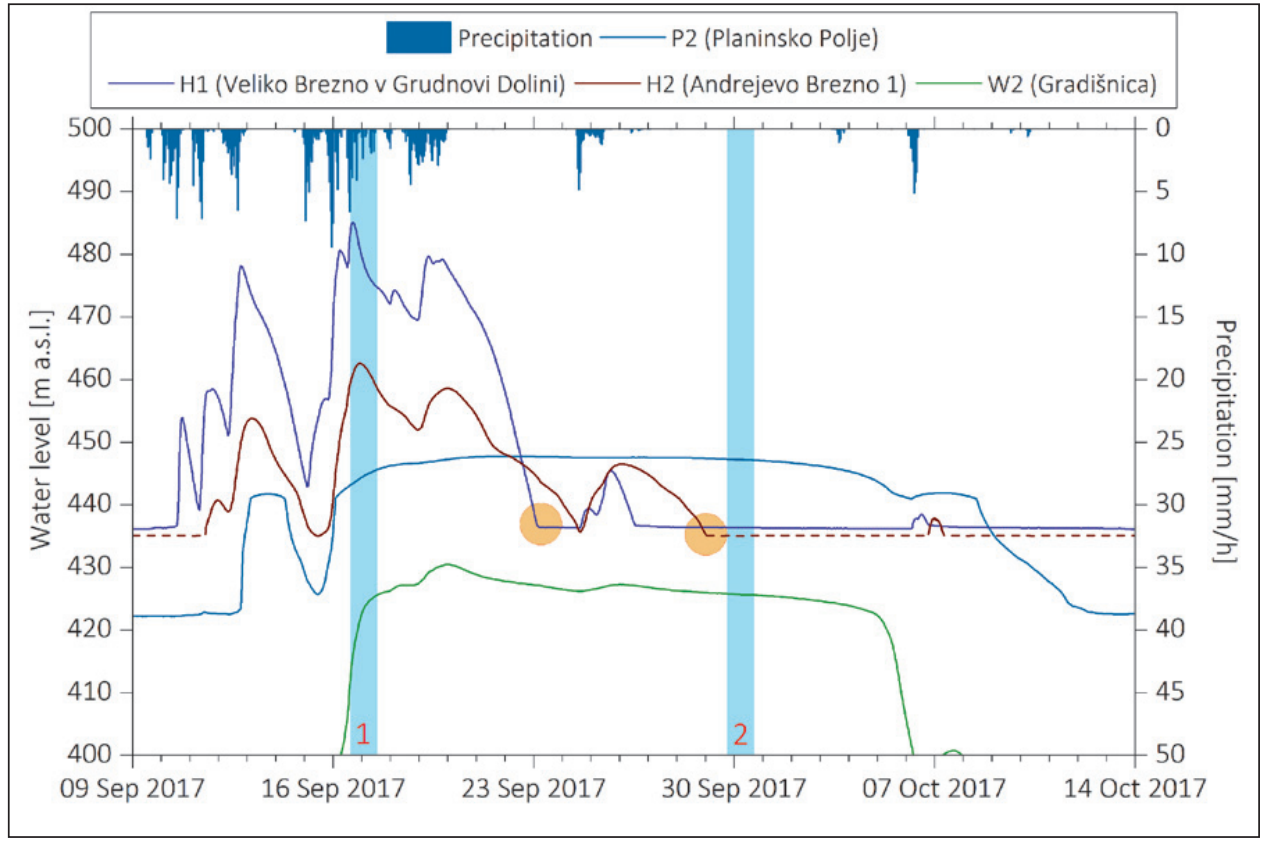

Fig. 19: Variations of water level on both sides of the IFZ during a selected high water event. Dashed line denotes periods when the water was below the position of the instrument at $\mathrm{H} 2$. Blue belts indicate the activation of the estavelles near Grčarevec functioning as spring (1) and ponor (2). Yellow circles indicate rapid transition from fast recession to a stable level. 
flooded. The outflow from the polje still keeps the level in $\mathrm{H} 2$ above the instrument. By the January $19^{\text {th }}$ the level at $\mathrm{H} 2$ receded below the instrument. Another precipitation event occurred on January $20^{\text {th }}$ and caused a rise of water level at $\mathrm{H} 2$ for 7-8 meters above the instrument (Fig. 22), but only a small disturbance is visible at H1. The level increase at $\mathrm{H} 2$ is also accompanied by a distinct drop of temperature, which clearly shows a mixing with cold water coming from the polje (Fig. 22).

Based on all observations given above, a SWMM model of the system has been made and tested (Figs. 23 \& 24). The model is a simplification of the reality: values of input flow and conduit diameters were assigned to reproduce water levels close to those observed. Nevertheless, it can be taken as a plausible setting aiming to capture the observed dynamics.

$\mathrm{H} 1$ and $\mathrm{H} 2$ receive a direct input representing both allogenic and autogenic recharge from the Hrušica Plateau. They are connected via a set of conduits (C1-C3) and join at the junction J, which is connected to W2 by the conduit C4. Input at PP is flow from Planinsko Polje, which is represented as a large reservoir. To account for the flow barrier, the conduit draining $\mathrm{H} 1$ has an inlet positioned at $436 \mathrm{~m}$ a.s.l. Fig. 25 shows the response of a a)

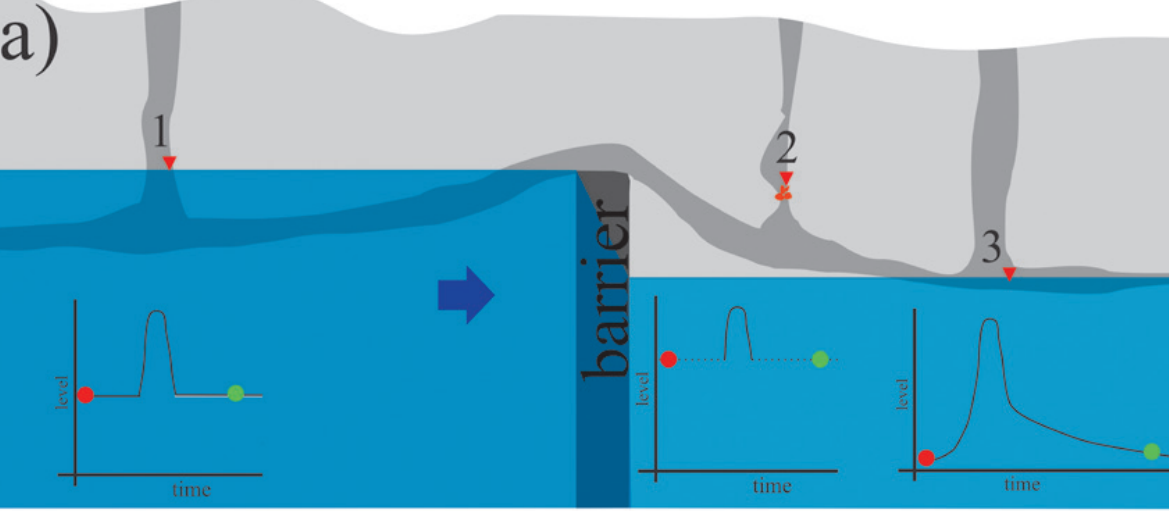

b)

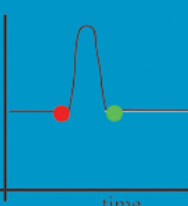

c)

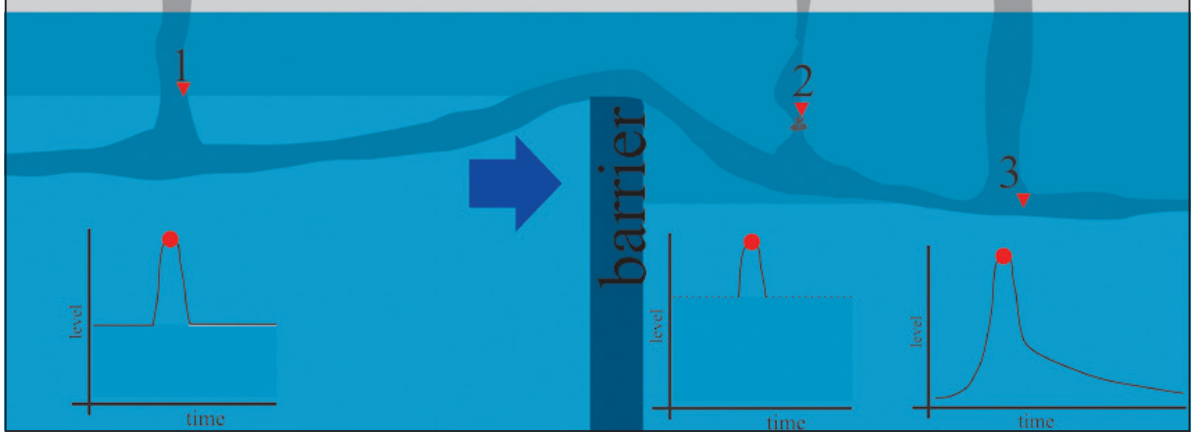

Fig. 20: Conceptual model of a system with a hydrogeological barrier and differently positioned caves. a) Low water situation; b) Rising (red dots on the level hydrographs) and falling (green dots on the level hydrographs) stage of a flood event; c) Maximal water level. 
hypothetical event and the calculated flow along the conduit connecting the polje to H2. The water level dynamics observed in the system is well captured by the model as well as the behaviour of estavelles.

A comparison between the monitored data and the modelling results allows the following interpretation of the regional flow dynamics:

- The rise of water level in $\mathrm{H} 1$ and $\mathrm{H} 2$ is caused by backflooding due to a limited outflow from the region located north from Idrija Fault Zone.
- The stable hydrograph characteristics at $\mathrm{H} 1$ indicate a flow barrier and an overflow from the Hrušica Plateau through a highly transmissive zone.

- When the water level in the region of $\mathrm{H} 1$ and $\mathrm{H} 2$ is above Planinsko Polje, springs below Grčarevec are activated and contribute to discharge in the polje.

- Recession is fast in $\mathrm{H} 1$ and H2. When the level in H1 and $\mathrm{H} 2$ drops below the polje's level the lowest springs below Grčarevec turn into ponors and prolong the recession in $\mathrm{H} 2$.
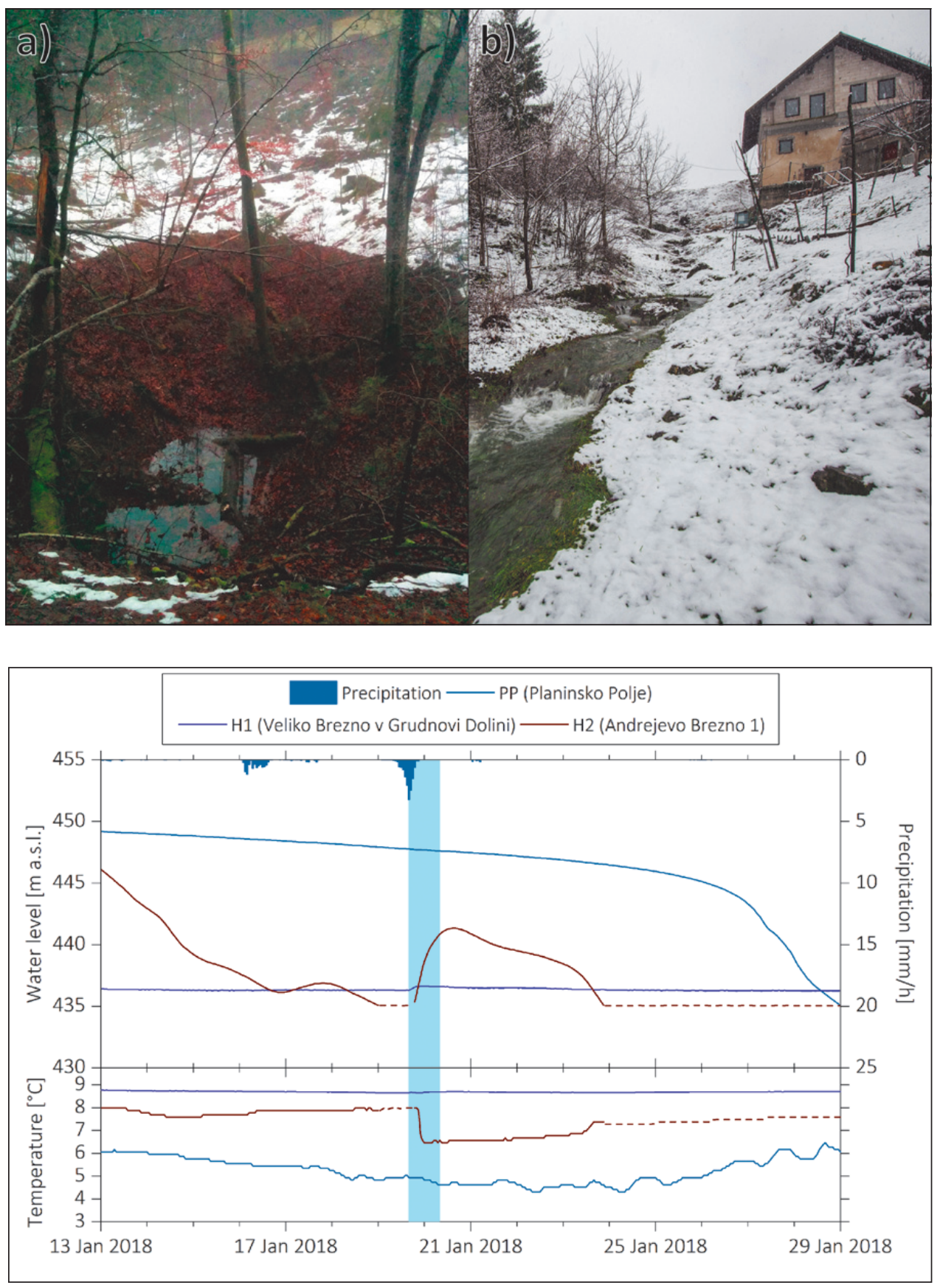

Fig. 21: a) Water in the entrance doline of H1 just a few hours after reaching its highest position on December $12^{\text {th }}, 2017$ (Photo: A. Mihevc). b) Temporary springs in the village of Grčarevec on December $13^{\text {th }}, 2017$. The estavelles are located downward (Photos: M. Blatnik).

Fig. 22: The situation at $\mathrm{H1}$ and $\mathrm{H} 2$ when the water recedes in Planinsko Polje. An additional rain event occurring on the January $20^{\text {th }}$ (blue belt) caused almost no change of water level in $\mathrm{H} 1$ (Veliko Brezno v Grudnovi Dolini), but a distinct rise in H2 (Andrejevo Brezno 1), due to the additional inflow from Planinsko Polje. 


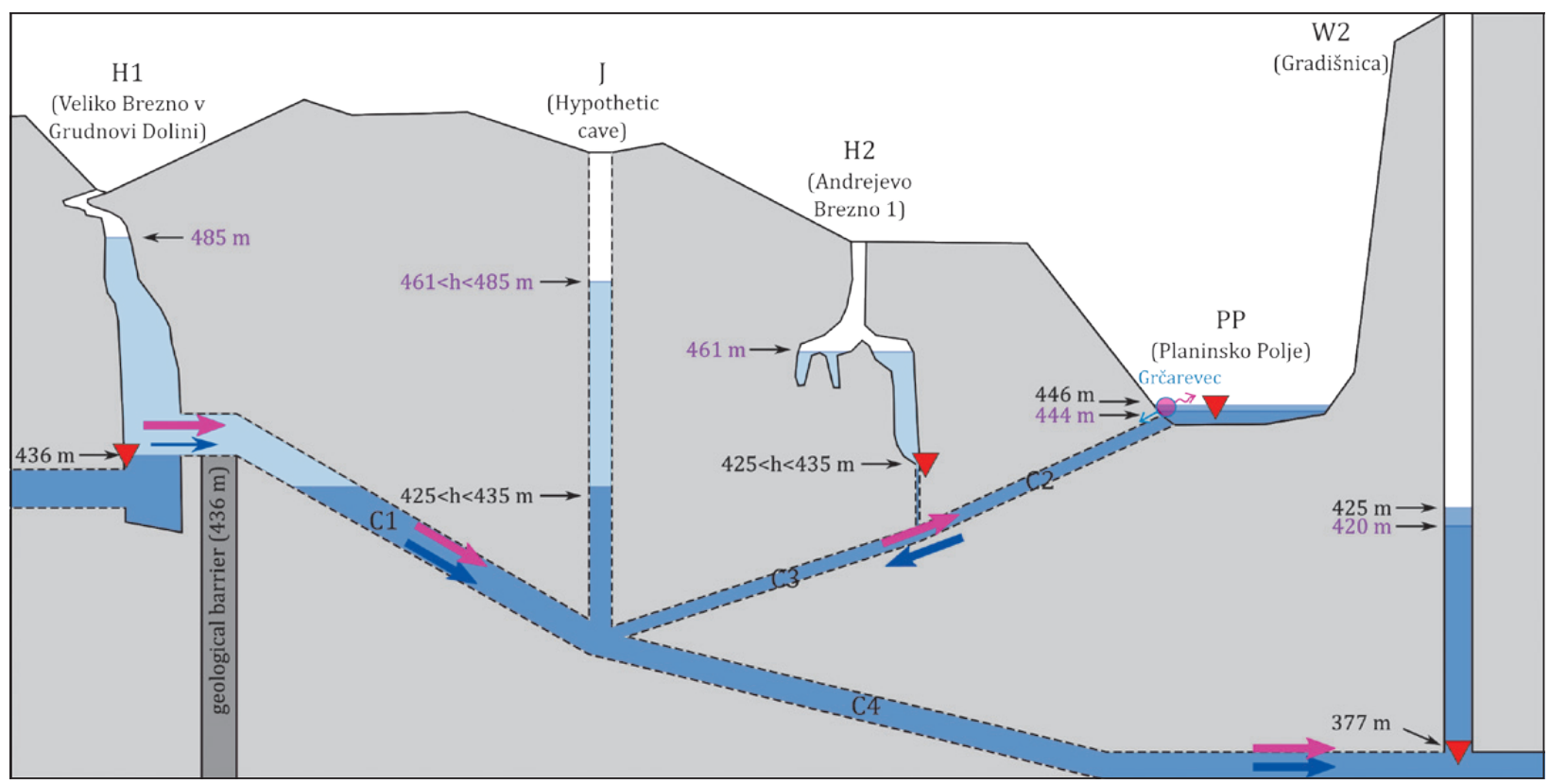

Fig. 23: Conduit model of the cave system between the Hrušica Plateau and Planinsko Polje. Pale blue colour and purple arrows indicate the situation during the peak of the flood (number 1 on Fig. 19) whereas dark blue colour and blue arrows show the situation following the recession in $\mathrm{H} 1$ and $\mathrm{H} 2$ (number 2 on Fig. 19). Data loggers are indicated by red triangles.

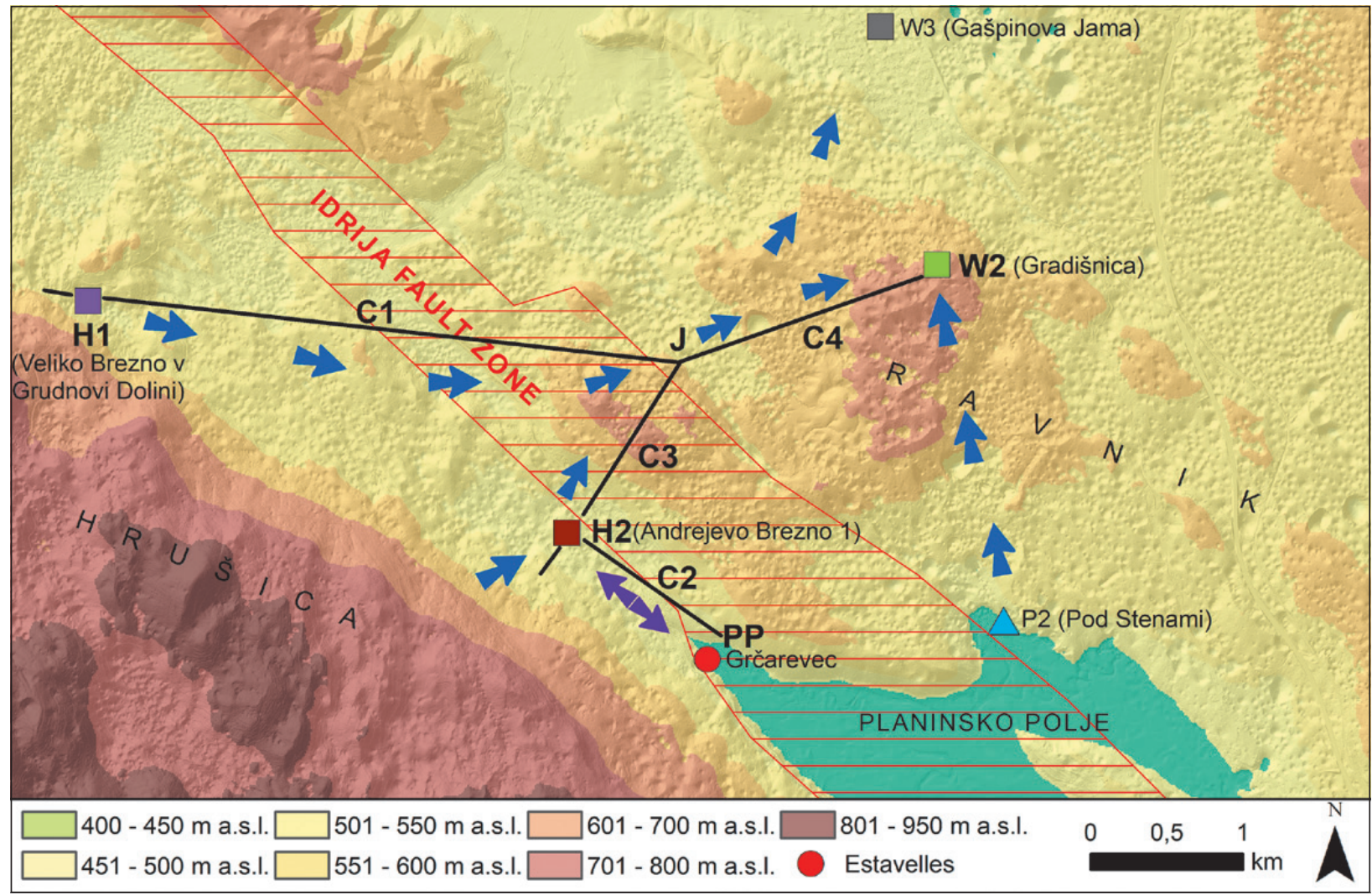

Fig. 24: Position of caves $\mathrm{H} 1$ and $\mathrm{H} 2$ with assumed flow directions. The purple arrow between Planinsko Polje and $\mathrm{H} 2$ indicates a flow reversion. The position of the springs and estavelles below Grčarevec are marked with a red circle. Black lines show position of conduits and nodes used in the numerical model. 


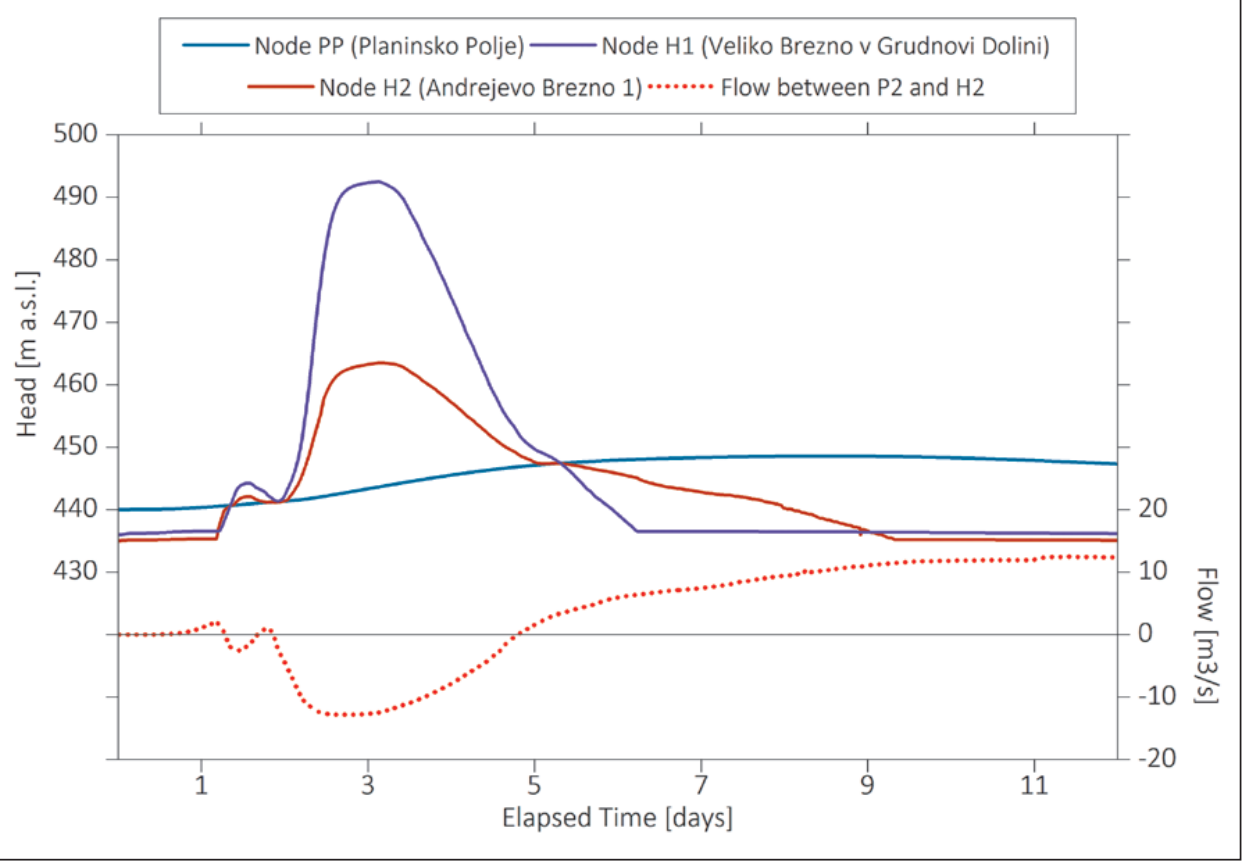

Fig. 25: Water level hydrograph of a modelled event for $\mathrm{H} 1, \mathrm{H} 2$ and $\mathrm{PP}$, and calculated flow from $\mathrm{PP}$ to $\mathrm{H} 2$ through C2. Negative values indicate reverse flow towards the polje.
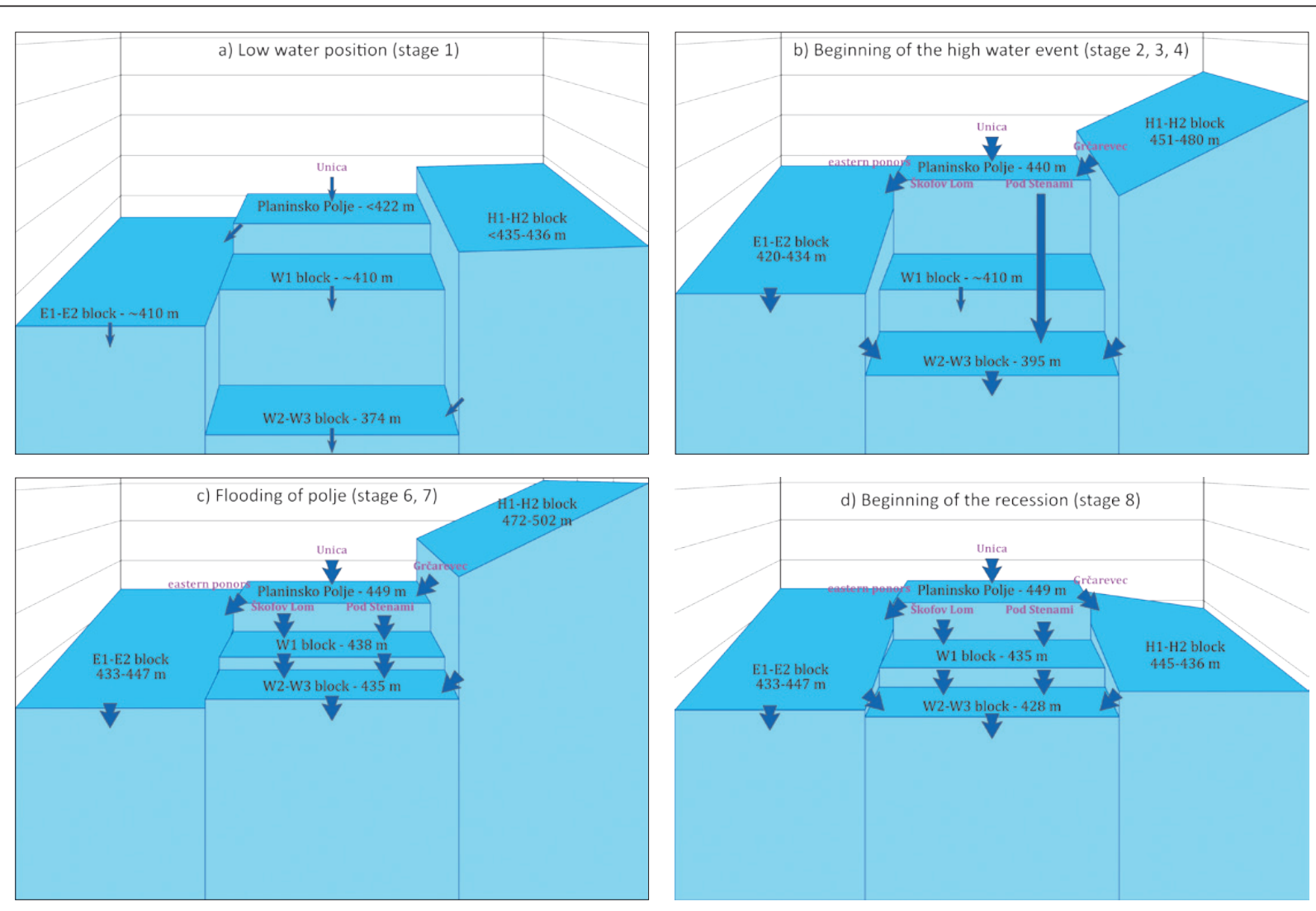

Fig. 26: Schematic view of the water level in determined blocks during various stages of high water event. The size of the arrows indicates the estimated amount of flow. The view is from the north (front) towards the south (back). 


\section{AN OUTLINE OF THE FLOOD DYNAMICS}

WITHIN THE ENTIRE OBSERVED SYSTEM

Each high water event has different characteristics resulting from different precipitation events and initial hydrological conditions. However, most of the major flood events share the following stages:

1. A pre-event low water position (Fig. 26a).

2. A response in caves $\mathrm{H} 1$ and $\mathrm{H} 2$ is observed. This region mainly receives an autogenic component from the Hrušica Plateau and Hotenjka region. The increase of water level in $\mathrm{H} 1$ and $\mathrm{H} 2$ activates the springs below Grčarevec (Figs. 19 \& 26b).

3. Direct infiltration and increase of the Unica River discharge cause a rise of water level and increase the outflow along the eastern ponors and reaction in caves $\mathrm{E} 1$ and E2 (Figs. 9 \& 26b).

4. A small response in W2 and W3 follows immediately, indicating their probable hydraulic connection to the eastern (P1-E1-E2) and/or the western (H1-H2) subsystems (Figs. 13 \& 26b).

5. The Unica River is routed over Planinsko Polje to- wards $\mathrm{P} 2$ and cause a significant rise in $\mathrm{W} 2$ and $\mathrm{W} 3$ (Figs. 12 \& 14).

6. When P2 is backflooded, part of the flow is diverted towards the ponors of Škofov Lom (P3). This causes a significant rise in $\mathrm{W} 1$ and an additional rise in $\mathrm{W} 2$ and W3 (Figs. 12 \& 26c)

7. The water level is at its highest stage in both polje and the draining aquifer (Fig. 26c).

8. Due to the fast recession occurring in the H1-H2 region, the estavelles below Grčarevec turn to ponors (Figs. $19 \& 26 \mathrm{~d}$ ).

9. The recession follows the inverse order of the rise: P3 (Škofov Lom) is the first ponor zone deactivated which cause the water level in W1 to drop first. After that, P2 (Pod Stenami) is deactivated and causes further step in recession at W2-W3 (Fig. 12). The final part of the recession at E1-E2 and W2-W3 is controlled by the decreasing outflow along the eastern ponors (P1) (Fig. 9).

Fig. 26 outlines the stages described above. Note that the Fig. shows the approximate position within blocks represented by the observation points and that the vertical faces between the blocks are physically not plausible.

\section{CONCLUSIONS}

Records of groundwater parameters obtained from the autonomous measurement network in water active caves provide significant information on the geometry and flow dynamics of karst systems. A careful inspection of hydrographs, combined with basic hydraulic rules and piecewise known geometry of epiphreatic conduits, allowed the construction of simple conceptual hydrological models. These models were tested numerically and adjusted in order to get a good qualitative fit to field data. Several new scenarios have been proposed to explain the functioning of the flow system between Planinsko Polje and springs of the Ljubljanica River. Although this work focuses to a specific region, the approach employed could be applied and further developed in other karst systems with complex and partially known epiphreatic geometry.

This work has shown the significance of the microlocation of the instruments. We are convinced that new locations having access to groundwater will be discovered in the future and that data recorded at these loca- tions would allow refining the understanding of the aquifer hydrology.

The models presented in this work are a simple but robust representation of the possible underground network and its hydrology. The simulations gave good qualitative fit to observations and the results clearly demonstrate the interpretative potential of simple hydraulic models, which allow testing different possible configuration of conduits and flow mechanisms. We are however aware that these models are oversimplified and that similar other representations might as well produce good qualitative fits. The use of more advanced computational approaches such as inversion procedures with automatic variations of assembly and geometry of conduit system is surely a promising way to reduce the model uncertainties in the future. However, we strongly believe that these models will need to use as many as possible field information. 


\section{ACKNOWLEDGEMENTS}

The work of M.B. was supported by the Young Researchers Programme of the Slovenian Research Agency (ARRS). The work of F.G. was supported by the Slovenian Research Agency (ARRS) under grants J5-7178 Integral system of flood sustainable spatial planning and J2-7322 Modelling hydrologic response of nonhomogeneous catchments and programme P6-0119. The work of C.M. was supported by the Slovenian Research Agency (ARRS) under grant L1-7555 Development and application of method for quantity and quality assessment of ground water resources in karst. DEM, hydrological and meteorological data provided by the Slovenian Environment Agency (ARSO) are highly appreciated. The authors would like to thank Franjo Drole for his assistance during field trips as well as the multiple generations of cavers from the local clubs of Ljubljana, Rakek, Logatec and Postojna, who are exploring the area around Planinsko Polje since about a century. We thank two reviewers (Andreas Hartmann and France Šušteršič) for pointing out several inconsistencies and suggested many meaningful improvements.

\section{REFERENCES}

ARSO, 2019a: Hydrological archive.- [Online] Available from: http://vode.arso.gov.si/hidarhiv/ [Accessed May $14^{\text {th }} 2019$ ].

ARSO, 2019b: Meteorological archive.- [Online] Available from: http://meteo.arso.gov.si/met/sl/archive/ [Accessed May 14 $4^{\text {th }}$ 2019].

ARSO, 2019c: Lidar data fishnet.- [Online] Available from: http://gis.arso.gov.si/ [Accessed May 14 ${ }^{\text {th }}$ 2019].

Audra, P. \& J.C. Nobécourt, 2012: Flooding in epiphreatic passages. Analysis of the 4-5 Nov. 2011 flood in the Chamois Cave (Alpes-de-Haute-Provence, France).- Proceedings of the 13th national Congress of Speleology, Muotathal, Swiss Society of Speleology, 103-108.

Berthelin, R. \& A. Hartmann, 2020. The Shallow Subsurface of Karst Systems: Review and Directions.In: Bertrand, C., Denimal, S., Steinmann, M. \& P. Renard (eds.): Eurokarst 2018, Besançon. Advances in Karst Science. Springer International Publishing, Cham, 61-68.

Blatnik, M., 2019: Groundwater distribution in the recharge area of Ljubljanica springs.- University of Nova Gorica, Graduate school, pp. 222, Nova Gorica.

Blatnik, M., Frantar, P., Kosec, D. \& F. Gabrovšek, 2017: Measurements of the outflow along the eastern border of Planinsko Polje, Slovenia.- Acta Carsologica, 46, 1, 83-93. DOI: 10.3986/ac.v46i1.4774

Brenčič, M., 2008. Vode Ljubljanskega barja in njegovega obrobja. In: Pavšič, J. (ed.): Ljubljansko barje: neživi svet, rastlinstvo, živalstvo, zgodovina in naravovarstvo. Društvo Slovenska matica, 17-31.

Cave register, 2019. Cave Register of the Karst Research Institute ZRC SAZU and Speleological Association of Slovenia. Postojna, Ljubljana.
Chen, Z. \& N. Goldscheider, 2014: Modeling spatially and temporally varied hydraulic behavior of a folded karst system with dominant conduit drainage at catchment scale, Hochifen-Gottesacker, Alps.- Journal of Hydrology, 514, 41-52. DOI: 10.1016/j.jhydrol.2014.04.005

Covington, M. D., Luhmann, A. J., Gabrovšek, F., Saar, M. O. \& C. M. Wicks, 2011: Mechanisms of heat exchange between water and rock in karst conduits.Water Resources Research, 47, W10514, DOI: 10.1029/2011WR010683

Cucchi, F., \& L. Zinni, 2002: Underground Timavo river monitoring.- Acta Carsologica, 31, 75-84.

Dingman, S. L., 2015. Physical hydrology, Third Edition.Waveland Press, pp. 643, Long Grove.

EPA, 2014. Storm Water Management Model (SWMM). US Environmental Protection Agency.

Frantar, P. (ed.), 2008: Water balance of Slovenia 19712000.- Ministrstvo za okolje in prostor, Agencija Republike Slovenije za okolje, pp. 119, Ljubljana.

Frantar, P. \& F. Ulaga, 2015: Visoke vode Planinskega polja leta 2014.- Ujma, 29, 66-73.

Gabrovšek, F. \& B. Peric, 2006: Monitoring of the flood pulses in the epiphreatic zone of karst aquifers: The case of Reka River system, Karst plateau, SW Slovenia.- Acta Carsologica, 35/1, 35-45. DOI: 10.3986/ ac.v35i1.241

Gabrovšek, F. \& J. Turk, 2010: Observations of stage and temperature dynamics in the epiphreatic caves within the catchment area of the Ljubljanica River (Slovenia).- Geologica Croatica, 63, 2, 187-193. DOI: $10.4154 /$ gc. 2010.16

Gabrovšek, F., Häuselmann, P. \& P. Audra, 2014: 'Looping caves' versus 'water table caves' : the role of base- 
level changes and recharge variations in cave development.- Geomorphology, 204, 683-691. DOI: 10.1016/j.geomorph.2013.09.016

Gabrovšek, F., Kogovšek, J., Kovačič, G., Petrič, M., Ravbar, N. \& J. Turk, 2010: Recent results of tracer tests in the catchment of the Unica River (SW Slovenia).- Acta Carsologica, 39, 1, 27-37. DOI: 10.3986/ac.v39i1.110

Gabrovšek, F., Peric, B. \& G. Kaufmann, 2018: Hydraulics of epiphreatic flow of a karst aquifer.- Journal of Hydrology, 560, 56-74. DOI: 10.1016/j.jhydrol.2018.03.019

Gabrovšek, F., Blatnik M. \& C. Mayaud, 2019: Epiphreatic flow in mature karst aquifers: theory, models and observations. In preparation.

Gams, I., 1965: On the Quarternary geomorphogenesis of the area among the karst poljes of Postojna, Planina and Cerknica (In Slovene, English Summary).Geografski vestnik, 37, 61-101.

Gams, I., 1980: Poplave na Planinskem polju.- Geografski zbornik, 20, 5-35.

Goldscheider, N. \& D. Drew (eds.), 2007: Methods in Karst Hydrogeology.- Taylor \& Francis, pp. 264, Leiden.

Gospodarič, R. \& P. Habič (eds.), 1976: Underground water tracing: Investigations in Slovenia 1972-1975.Inštitut za raziskovanje krasa ZRC SAZU, pp. 312, Postojna.

Gospodarič, R., 1981: Morfološki in geološki položaj kraških votin v ponornem obrobju Planinskega polja.- Acta Carsologica, 10, 157-172.

Häuselmann, P., Jeannin, P. Y. \& M. Monbaron, 2003: Role of epiphreatic flow and soutirages in conduit morphogenesis: the Bärenschacht example (BE, Switzerland).- Zeitschrift für Geomorphologie, NF, 47, 2, 171-190.

Jeannin, P., 2001: Modeling flow in phreatic and epiphreatic karst conduits in the Holloch cave (Muotatal, Switzerland).- Water Resources Research, 37, 2, 191-200. DOI: 10.1029/2000WR900257

Kaufmann, G., Gabrovšek, F. \& J. Turk, 2016: Modelling flow of subterranean Pivka River in Postojnska Jama, Slovenia.- Acta Carsologica, 45, 1, 57-70. DOI: $10.3986 /$ ac.v45i1.3059

Kaufmann, G., Mayaud, C., Kogovšek, B. \& F. Gabrovšek, 2019: Understanding the temporal variation of flow direction in a complex karst system (Planinska Jama, Slovenia).- Submitted to Acta Carsologica.

Kovačič, G. \& N. Ravbar, 2010: Extreme hydrological events in karst areas of Slovenia, the case of the Unica River basin.- Geodinamica Acta, 23, 1-3, 89-100. DOI: $10.3166 /$ ga.23

Krivic, P., Verbovšek, R. \& F. Drobne, 1976: Hidrogeološka karta 1: 50 000.- In: Gospodarič, R. \& P. Habič (eds.): Underground water tracing: Investigations in Slovenia 1972-1975. Inštitut za raziskovanje krasa ZRC SAZU, Postojna.

Mayaud, C., Gabrovšek, F., Blatnik, M., Kogovšek, B., Petrič, M. \& N. Ravbar, 2019: Understanding flooding in poljes: a modelling perspective.- Journal of Hydrology, 575, 874-889. DOI: https://doi. org/10.1016/j.jhydrol.2019.04.092

Mihevc, A., 2014: Voda potrebuje prostor.- [Online] Available from: https://www.mladina.si/154376/ voda-potrebuje-prostor/ [Accessed May 14 ${ }^{\text {th }} 2019$ ].

ONSET Comp, 2018a: HOBO ${ }^{\star}$ U20 Water Level Logger (U20-001-0x and U20-001-0x-Ti) Manual.- [Online] Available from: http://www.onsetcomp.com/ files/manual_pdfs/12315-J\%20U20\%20Manual.pdf [Accessed May 14 ${ }^{\text {th }} 2019$ ].

ONSET Comp, 2018b: HOBO ${ }^{\circ}$ U24 Conductivity Logger (U24-001) Manual.- [Online] Available from: https://www.onsetcomp.com/files/manual_pdfs/15070-I\%20U24-001\%20Manual.pdf [Accessed May 14 ${ }^{\text {th }} 2019$ ].

Palmer, A. N., 2007: Cave Geology.- Cave Book, pp. 454. Dayton.

Peterson, E. \& C. Wicks, 2006: Assessing the importance of conduit geometry and physical parameters in karst systems using the storm water management model (SWMM).- Journal of Hydrology, 329, 294-305. DOI: 10.1016/j.jhydrol.2006.02.017

Placer, L., 1981: Geološka zgradba jugozahodne Slovenije.- Geologija, 24, 1, 27-60.

Placer, L., Vrabec, M. \& B. Celarc, 2010: The bases for understanding of the NW Dinarides and Istria Peninsula tectonics.- Geologija, 53, 1, 55-86. DOI: 10.5474/geologija.2010.005

Pleničar, M., 1970: Tolmač osnovne geološke karte 1:100.000, List Postojna.- Zvezni geološki zavod, Beograd.

Putick, V., 1889: Die hydrologischen Geheimnisse des Karstes und seine unterirdischen Wasserläufe : auf Grundlage der neuesten hydrotechnischen Forschungen.- Himmel und Erde, pp. 13, Berlin.

Ravbar, N., Petrič, M., Kogovšek, B., Blatnik, M. \& C. Mayaud, 2018: High waters study of a Classical Karst polje - An example of the Planinsko Polje, SW Slovenia.- In: Milanović, S. \& Z. Stevanović (eds.): Proceedings of the International Sympsium KARST 2018 "Expect the Unexpected", 6-9 June 2018, Trebinje. Belgrade: Centre for Karst Hydrogeology; Trebinje: Hydro-Energy Power Plant "Dabar", 417-424.

Rossman, L. A., 2015: Storm Water Management Model User's Manual Version 5.1.- U.S. Environmental Protection Agency, pp. 352. 
Savnik, R., 1960: Hidrografsko zaledje Planinskega polja.- Geografski vestnik, 32, 212-224.

Schlumberger Water Services, 2018: Diver Manual.[Online] Available from: https://www.daiki.co.jp/ Manual/Diver\%20(GB)\%20HL341v3.pdf [Accessed May $14^{\text {th }} 2019$ ].

Shaw, T. \& A. Čuk, 2015: Slovene karst and caves in the past.- Inštitut za raziskovanje krasa ZRC SAZU, pp. 464, Postojna.

Šušteršič, F., 1996: Poljes and caves of Notranjska.- Acta Carsologica, 25, 251-290.

Šušteršič, F., 2002: Where does Underground Ljubljanica Flow?.- RMZ Materials and Geoenvironment, 49, 1, 61-84.

Šušteršič, F., 2006: Relationships between deflector faults collapse dolines and collector channel formation.International Journal of Speleology, 35, 11-12. DOI: 10.5038/1827-806X.35.1.1
Turk, J., 2010: Dinamika podzemne vode v kraškem zaledju izvirov Ljubljanice - Dynamics of underground water in the karst catchment area of the Ljubljanica springs.- Inštitut za raziskovanje krasa ZRC SAZU, pp. 136, Postojna.

Vrabec, M., 1994: Some thoughts on the pull-apart origin of karst poljes along the Idrija strike-slip fault zone in Slovenia, Acta Carsologica, 23, 155-167.

Worthington, S. R. H., 1999: A comprehensive strategy for understanding flow in carbonate aquifers.- In: Palmer, A. N., Palmer, M. V. \& I. D. Sasowsky (eds.): Karst Modelling. Charlottesville, Virginia: Karst Waters Institute, 30-37. 